\title{
Egr3-Dependent Muscle Spindle Stretch Receptor Intrafusal Muscle Fiber Differentiation and Fusimotor Innervation Homeostasis
}

\author{
Michelle Oliveira Fernandes ${ }^{1,3}$ and Warren G. Tourtellotte ${ }^{1,2,3}$ \\ ${ }^{1}$ Department of Pathology (Division of Neuropathology), ${ }^{2}$ Department of Neurology, and ${ }^{3}$ Northwestern University Driskill Graduate Program, Feinberg \\ School of Medicine, Northwestern University, Chicago, Illinois 60611
}

\begin{abstract}
Muscle stretch proprioceptors (muscle spindles) are required for stretch reflexes and locomotor control. Proprioception abnormalities are observed in many human neuropathies, but the mechanisms involved in establishing and maintaining muscle spindle innervation and function are still poorly understood. During skeletal muscle development, sensory (Ia-afferent) innervation induces contacted myotubes to transform into intrafusal muscle fibers that form the stretch receptor core. The transcriptional regulator Egr3 is induced in Ia-afferent contacted myotubes by Neuregulin1 (Nrg1)/ErbB receptor signaling and it has an essential role in spindle morphogenesis and function. Because Egr3 is widely expressed during development and has a pleiotropic function, whether Egr3 functions primarily in skeletal muscle, Ia-afferent neurons, or in Schwann cells that myelinate Ia-afferent axons remains unresolved. In the present studies, cell-specific ablation of Egr 3 in mice showed that it has a skeletal muscle autonomous function in stretch receptor development. Moreover, using genetic tracing, we found that Ia-afferent contacted Egr3-deficient myotubes were induced in normal numbers, but their development was blocked to generate one to two shortened fibers that failed to express some characteristic myosin heavy chain $(\mathrm{MyHC})$ proteins. These "spindle remnants" persisted into adulthood, remained innervated by Ia-afferents, and expressed neurotrophin3 (NT3), which is required for Ia-afferent neuron survival. However, they were not innervated by fusimotor axons and they did not express glial derived neurotrophic factor (GDNF), which is essential for fusimotor neuron survival. These results demonstrate that Egr3 has an essential role in regulating gene expression that promotes normal intrafusal muscle fiber differentiation and fusimotor innervation homeostasis.
\end{abstract}

Key words: Egr3; GDNF; intrafusal muscle fiber; muscle spindle; NT3; proprioception

\section{Introduction}

Muscle spindles are stretch-sensitive mechanoreceptors embedded within skeletal muscles that mediate limb and axial body position sensation (proprioception), the myotatic stretch reflex and locomotor patterning (Poppele and Terzuolo, 1968; Goodwin et al., 1972; Akay et al., 2014). Spindles consist of encapsulated intrafusal muscle fibers that are innervated by specialized group Ia-afferents that relay muscle stretch sensation to the CNS and fusimotor efferents that maintain spindle stretch sensitivity as muscles stretch and contract. During skeletal muscle development, Ia-afferents make contact with myotubes and release Neuregulin1 (Nrg1) to engage myotube ErbB2/B4 receptor-mediated

Received Jan. 19, 2015; revised Feb. 23, 2015; accepted March 2, 2015.

Author contributions: M.O.-F. and W.G.T. designed research; M.O.-F. and W.G.T. performed research; M.0.-F. and W.G.T. analyzed data; M.O.-F. and W.G.T. wrote the paper.

This work was supported by the National Institutes of Health (Grants R01-NSO40748, K02-NS046468, and K260D026099). We thank K. Gruner in the Tourtellotte laboratory and L. Li and members of the Mouse Histology and Phenotyping Laboratory (MHPL) for technical assistance. Dr. Tourtellotte is the Director of the Mouse Histology and Phenotyping Laboratory, which is supported by Grant P30-CA060553-20-7341 from the National Institutes of Health.

The authors declare no competing financial interests.

Correspondence should be addressed to Warren G. Tourtellotte, MD, PhD, FCAP, Northwestern University, Feinberg School of Medicine, Department of Pathology, Ward Bldg., Rm. 3-240, 303 E. Chicago Ave., Chicago, IL 60611. E-mail:warren@northwestern.edu.

DOI:10.1523/JNEUROSCI.0241-15.2015

Copyright $\odot 2015$ the authors $\quad 0270-6474 / 15 / 355566-13 \$ 15.00 / 0$ gene expression that drives spindle morphogenesis (Andrechek et al., 2002; Hippenmeyer et al., 2002; Leu et al., 2003). Although downstream gene regulation engaged by Nrg1/ErbB signaling in Ia-afferent contacted myotubes is only partially characterized, it induces spindle development and stretch reflex morphogenetic programs, in part by upregulating transcriptional regulators such as Egr3, ER81, Pea3, and Erm (Tourtellotte and Milbrandt, 1998; Arber et al., 2000; Hippenmeyer et al., 2002; Jacobson et al., 2004). In addition, developing intrafusal muscle fibers upregulate retrograde feedback signaling mediators that are essential for normal proprioceptive neuron survival and innervation, such as neurotrophin3 (NT3) (Ernfors et al., 1994; Oakley et al., 1995) and for fusimotor neuron survival and innervation, such as glial derived neurotrophic factor (GDNF) (Whitehead et al., 2005; Gould et al., 2008; Shneider et al., 2009b).

Egr3 expression is essential for normal spindle morphogenesis, proprioception, and coordinated locomotor function (Tourtellotte et al., 2001; Akay et al., 2014), but the extent to which it has an essential role within developing intrafusal muscle fibers is not clear because it is widely expressed and has a highly pleiotropic function (Tourtellotte and Milbrandt, 1998; Li et al., 2005; Carter et al., 2007; Gao et al., 2007; Eldredge et al., 2008). To examine the cell autonomous role of Egr3 in spindle morphogenesis, we generated Egr3 conditional knock-out mice and systematically ablated Erg3 in proprioceptive sensory neurons, Schwann 
cells that thickly myelinate proprioceptive axons and skeletal muscle. Whereas Egr3 ablation in proprioceptive neurons and Schwann cells had no effect on spindle morphogenesis or proprioception, Egr3 ablation in skeletal muscle resulted in abnormal spindle development and function. Moreover, we generated Egr3 Cre-recombinase knock-in mice that made it possible to trace the fate of Egr3-deficient Ia-afferent contacted myotubes. Although Ia-afferents appeared to engage early spindle development in the absence of Egr3, intrafusal-like muscle fibers failed to differentiate beyond one to two shortened fibers and failed to express some characteristic intrafusal muscle fiber proteins. Although they expressed NT3 and maintained their Ia-afferent innervation, they failed to express the fusimotor neuron survival factor GDNF and were never found to have motor endplates or fusimotor innervation.

Together, these results indicate that Ia-afferent innervation in developing skeletal muscle can initiate spindle morphogenetic signaling, but it is not sufficient to drive normal spindle development or function in the absence of Egr3. Egr3 appears to be a master regulator of intrafusal muscle fiber differentiation and GDNF expression required for establishing and maintaining their fusimotor innervation.

\section{Materials and Methods}

Animals. Egr3-flx $\left(\mathrm{Egr}^{+/ \mathrm{flx}}\right)$ and Egr3-Cre $\left(\mathrm{Egr}^{+/ \mathrm{Cre}}\right)$ mice were generated and genotyped as described previously (Quach et al., 2013). Previously characterized Cre recombinase-driver mice were used for cell-lineage-specific Egr3 ablation. We used P0-Cre for Schwann cells, a generous gift from L. Wrabetz, SUNY Buffalo (Feltri et al., 1999), Parvalbumin (Pv)-Cre for proprioceptive neurons, a generous gift from S. Arber, University of Basel Switzerland (Hippenmeyer et al., 2005), HSACre for skeletal muscle, a generous gift from J. Melki, University of Paris (Miniou et al., 1999), and $\beta$-actin-Cre for widespread ablation, obtained from Jackson Laboratories (catalog \#003376; Lewandoski et al., 1997). R26R Jackson Laboratories catalog \#003474; Soriano, 1999) and Ai14 (Jackson Laboratories catalog \#007098; Madisen et al., 2010) Crerecombinase reporter mice were obtained from Jackson Laboratories. All animals were genotyped by PCR using genomic DNA isolated from tail biopsy tissue. Mice of either sex were used because no differences in spindle development were identified between the sexes. The PCR primer sequences used for genotyping are available upon request.

All experimental procedures complied with the Public Health Service Policy on Humane Care and Use of Laboratory Animals and all animalrelated protocols were approved by the Northwestern University Institutional Animal Care and Use Committee.

Tissue preparation. Gastrocnemius, soleus, and plantaris hindlimb muscles were dissected from 8- to 10-week-old mice or full hindlimbs were collected from neonates up to 2 days after birth. Fresh tissues were collected after transcardiac perfusion with $0.1 \mathrm{M}$ PBS, pH 7.4, partially embedded in Tragacanth gum (Sigma G-1128; $10 \%$ w/v with water containing $1 \%$ phenol) as a mounting medium, immediately frozen in liquid-nitrogen-chilled isopentane, and stored at $-80^{\circ} \mathrm{C}$. Some animals received transcardiac perfusion with $0.1 \mathrm{M} \mathrm{PBS} / 4 \%$ paraformaldehyde (PFA), $\mathrm{pH} 7.4$, and tissues were postfixed in 4\% PFA for $2 \mathrm{~h}$, cryoprotected at $4^{\circ} \mathrm{C}$ in graded (15-30\%) sucrose/PBS, and embedded in OCT compound. Some animals were perfused and tissues were postfixed with modified Zamboni's fixative ( $2 \%$ PFA, $15 \%$ picric acid, $0.1 \mathrm{M} \mathrm{PB}, \mathrm{pH}$ 7.4). All tissues were serial sectioned on a cryostat at $12 \mu \mathrm{m}$ thickness. For some experiments, genomic DNA was isolated from brain, heart, liver, kidney, dorsal root ganglia (DRG), hindlimb, tongue, and tail to evaluate tissue-specific and Cre-recombinase-dependent allele recombination by PCR.

Resin processing. Animals were perfused with PBS, pH 7.4, followed by glutaraldehyde fixation (2.5\% glutaraldehyde, $2 \%$ PFA, $0.1 \mathrm{~m}$ cacodylate buffer; $\mathrm{pH}$ 7.4). The gastrocnemius, soleus, and plantaris muscles were dissected, postfixed for $24 \mathrm{~h}$, and transferred to $0.1 \mathrm{M}$ cacodylate buffer. Ventral nerve roots were transferred to $1 \%$ osmic acid, dehydrated through graded alcohols (30-100\%), and infiltrated with graded $100 \%$ propylene oxide and 100\% Embed-812 resin (Electron Microscopy Sciences) before polymerization at $60^{\circ} \mathrm{C}$. The resin blocks were sectioned at $1 \mu \mathrm{m}$ and stained with $1 \%$ toluidine blue.

Ventral root axon morphometry. Toluidine-blue-stained, resinembedded cross-sections of ventral roots were photomicrographed using a digital camera (Spot Imaging RT slider) with $100 \times$ oil-immersion optics and the photographs were assembled into composites using Adobe Photoshop software. The calibrated composite images of highresolution nerve root cross-sections were analyzed with image analysis software (MetaMorph) using Feret analysis to calculate the diameter of a cylinder having similar cross-sectional area. For each ventral root, small-diameter, thickly myelinated axons $<3.5 \mu \mathrm{m}$ in diameter were classified as fusimotor axons and counted as a percentage of the total number of thickly myelinated axons within the entire root as described previously (Tourtellotte and Milbrandt, 1998; Tourtellotte et al., 2001).

Immunohistochemistry. Fixed or fresh-frozen tissue sections were airdried for 20 min and blocked with PBS/0.3\% Triton X-100 (PBST) and $5 \%$ serum for $1 \mathrm{~h}$ at room temperature (RT). Primary antibody incubation was performed overnight in $\mathrm{PBST} / 5 \%$ serum at RT using the following antibodies: ATP $1 \alpha 3$ (rabbit anti-ATP1 $\alpha 3,1: 1000$; Millipore), $\beta$-galactosidase ( $\beta$-gal; chicken anti- $\beta$-gal, 1:1000; Abcam or goat anti$\beta$-gal, 1:500; ABD Serotec or rabbit anti- $\beta$-gal, 1:500; ICN), Egr3 (rabbit anti-Egr3, 1:1000; Santa Cruz Biotechnology), GDNF (rabbit antiGDNF, 1:250; LSBio), laminin (chicken anti-laminin, 1:5000; Sigma or rabbit anti-Laminin, 1:1000; Sigma), NT3 (rabbit anti-NT3, 1:500; LSBio), Pv (goat anti-Pv, 1:1000; Swant), s100 $\beta$ (goat anti-s100 $\beta, 1: 100$; Santa Cruz Biotechnology) and TrkC (goat anti-TrkC, 1:1000; R\&D Systems). The following antibodies from the Developmental Studies Hybridoma Bank were used on fresh-frozen muscle tissues: $6 \mathrm{H} 1$ [anti-2X myosin heavy chain (MyHC), 1:500], 10F5 (anti-2B MyHC, 1:40), BA-F8 (anti- $\alpha$ - and $\beta$-slow MyHC, 1:40), BF-G6 (anti-embryonic MyHC, 1:40), and MF30 (anti-neonatal and adult MyHC, 1:40). Citrate buffer heat-induced epitope retrieval was used before immunostaining for ATP1 $\alpha 3$, Egr3, NT3, and TrkC, at pH 6.0 and for GDNF at pH 9.0. In some experiments, tyramide signal amplification (New England $\mathrm{Nu}-$ clear) was used to amplify the antigen detection signal. Primary antibody binding was detected by $1 \mathrm{~h}$ incubation with Cy3 (Jackson ImmunoResearch), Alexa Fluor 488 (Invitrogen), or DyLight 647 (Thermo Fisher Scientific) fluorophore-conjugated species-specific secondary antibodies in PBS/2\% serum. $\alpha$-Bungarotoxin (1:500; Invitrogen) was used to visualize acetylcholine receptors at motor endplates (MEPs) as indicated. Nuclei were visualized by Hoechst 33342 (bisbenzamide/Bis) staining (1 $\mu \mathrm{g} / \mathrm{ml}$ ) and slides were coverslipped with gelvatol mounting medium.

Immunohistochemistry on mouse tissues with mouse monoclonal antibodies. For immunohistochemistry (IHC), primary mouse antibodies to $\mathrm{MyHC}$ isoforms were preincubated along with anti-mouse fluorophorelabeled secondary antibody in $\mathrm{PBST} / 5 \%$ serum at $4^{\circ} \mathrm{C}$ for $15 \mathrm{~min}$ in the dark. Normal mouse serum was slowly added to the tube to a final concentration of $1.5 \%$ and further mixed at $4^{\circ} \mathrm{C}$ for $15 \mathrm{~min}$ in the dark. Tissue sections were incubated overnight at RT in the dark with the antibody complexes. When two-channel immunofluorescence was performed, slides were washed twice with PBS and incubated with speciesappropriate secondary antibodies diluted in PBS with $2 \%$ serum for $1 \mathrm{~h}$ at RT. The slides were then washed with PBS, stained with Hoechst 33342 (1 $\mu \mathrm{g} / \mathrm{ml})$, and coverslipped with gelvatol mounting medium.

LacZ ( $\beta$-gal) enzyme histochemistry. Tissues from newborn or 8-weekold mice were fixed, processed, and sectioned as described previously. Slides were air-dried for $20 \mathrm{~min}$ and rinsed in PBS before a $10 \mathrm{~min}$ fixation in $0.2 \%$ glutaraldehyde, $5 \mathrm{~mm}$ EGTA, $100 \mathrm{~mm}$ magnesium chloride in $0.1 \mathrm{M}$ PBS at RT. This was followed by 3 washes in wash buffer ( $0.01 \%$ sodium deoxycholate, $0.02 \% \mathrm{NP}-40,2 \mathrm{~mm}$ magnesium chloride in PBS) for $5 \mathrm{~min}$ each. Slides were incubated in reaction buffer $[1 \mathrm{mg} / \mathrm{ml}$ 5-bromo-4-chloro-3-indolyl- $\beta$-D-galactopyranoside (X-gal), $5 \mathrm{~mm}$ potassium ferrocyanide, $5 \mathrm{~mm}$ potassium ferricyanide in wash buffer)] night at $37^{\circ} \mathrm{C}$ and rinsed in $2 \mathrm{~mm}$ magnesium chloride/PBS. Slides were dehydrated in gradient alcohol baths (70-100\%) and coverslipped with xylene-based mounting medium. 
Muscle spindle counts. The medial gastrocnemius, soleus, and plantaris hindlimb muscles from 8 -week-old mice were frozen and serially crosssectioned through the full length of the muscles into 4 parallel series of sections at $12 \mu \mathrm{m}$ thickness. One full series of sections was stained with $\mathrm{H} \& \mathrm{E}$, lacZ histochemistry, or $\beta$-gal IHC as appropriate to identify muscle spindles by their characteristic morphology or lac $Z / \beta$-gal tracer content. A full series of sections was used to analyze all the muscle spindles contained within a single specific muscle and to examine protein content determined by IHC along their entire length within the muscle. Serial sections were examined and muscle spindles were mapped to ensure that each spindle was counted only once. On average, 50 slides were processed for IHC and/or analyzed for spindle counts and innervation for each animal/muscle. A minimum of three animals from each genotype were analyzed for each hindlimb muscle and the results are represented as mean \pm SEM. Student's $t$ test was used to compare means and $p<0.05$ was considered statistically significant.

Whole-mount IHC. Intact sciatic nerves were stained by IHC immediately after dissection. In some cases, individual axons were teased from the intact nerves in PBS, fixed in 2\% PFA, rinsed in PBST, and processed for IHC. Immunolabeled sciatic nerves were mounted on glass slides, coverslipped, and imaged on a confocal microscope.

Rotarod and treadmill testing. Four-week-old mice were weighed and acclimated on a rotarod (Ugo Basile) before data collection (Dunham and Miya, 1957). The rod was cleaned and operated in a laminar flow hood to maintain sterile conditions. Mice were placed on the rotating rod ( $4 \mathrm{rpm}$ ) and the speed was increased by 4 rpm every $30 \mathrm{~s}$ until it reached $40 \mathrm{rpm}$, after which the speed remained constant. The time to fall from the rod after it was switched on was recorded. Each animal performed the task 3 times with 8-10 min intervals between trials. Similarly, mice were placed on a treadmill and tested at different speeds $(10-30 \mathrm{~cm} / \mathrm{s})$ to determine the fastest speed at which they could run and stay on the treadmill. Four to eight mice of each genotype were analyzed and results are reported as mean \pm SEM. Student's $t$ test was used to compare means and $p<0.05$ was considered statistically significant.

\section{Results}

Egr3 expression in cells mediating the myotatic stretch reflex and proprioception

Muscle spindle stretch receptors are innervated by group Ia-afferents from DRG neurons and specialized fusimotor $(\gamma)$ efferents from spinal cord motor neurons (Fig. 1A). Group Ia-afferent, but not fusimotor efferent, innervation to a subpopulation of skeletal myotubes is essential to initiate intrafusal muscle fiber differentiation during spindle morphogenesis (Zelená, 1957; Zelená and Soukup, 1973; Kucera and Walro, 1992). The transcriptional regulator Egr3 is expressed in Ia-afferent contacted myotubes during the earliest stages of spindle morphogenesis, where it may have an essential function during intrafusal muscle fiber development (Tourtellotte and Milbrandt, 1998; Tourtellotte et al., 2001; Albert et al., 2005; Fig. 1A,B). However, Egr3 is also expressed in Schwann cells (Gao et al., 2007), which myelinate Ia-afferent axons, and in the DRG, where it may have a role in modulating proprioceptive neuron function during spindle development. To characterize the expression of Egr3 in proprioceptive DRG neurons, nerves, and spindle stretch receptor muscle fibers or their lineage precursors during development, we generated Egr $3^{+/ C r e}$ knock-in mice that express Cre-recombinase regulated by the endogenous Egr3 gene locus (Quach et al., 2013). Egr3 ${ }^{+/ C r e}$ mice were mated to R26R Cre-recombinase reporter mice (Soriano, 1999), which made it possible to trace Egr3 expression using lacZ histochemistry even if Egr3 expression was transient during lineagespecified precursor cell development (Fig. 1C). In Egr3 ${ }^{+/ C r e}$; $\mathrm{R}_{26 \mathrm{R}^{+/ f l x}}$ mice, historical Egr3 expression was identified using lacZ histochemistry in DRG, nerves, and muscle spindles in postnatal mice. In the DRG, lacZ expression was confined mostly to intraganglionic nerve fibers, but some ganglionic neurons were also labeled (Fig. 1D). In myelinated nerves, lacZ expression was observed in a pattern that appeared to correspond to Schwann cells because most staining was in cells that surrounded axons (Fig. $1 E)$. In muscle spindles, lacZ expression was observed in all intrafusal muscle fibers and the surrounding spindle capsule, consistent with the pattern of Egr3 expression described previously (Tourtellotte and Milbrandt, 1998; Fig. 1F). LacZ staining was never observed in extrafusal skeletal muscle fibers or in spinal cord motor neurons, indicating that neither they nor their precursors ever express Egr3. Therefore, abnormal spindle development in mice lacking Egr3 in all tissues (germline knock-out mice) could result from its loss in DRG, nerves, or muscle.

\section{Egr3 expression in DRG proprioceptive neurons has no role in spindle morphogenesis}

Skeletal muscle innervation by group Ia-proprioceptive axons to otherwise undifferentiated myotubes at approximately embryonic day 14.5 (E14.5) is essential for inducing muscle spindle morphogenesis (Ernfors et al., 1994; Fariñas et al., 1994; Klein et al., 1994; Tessarollo et al., 1994), raising the possibility that Egr3 expression in proprioceptive neurons may have a role in the abnormal spindle development that occurs in mice lacking Egr3 in all tissues (Tourtellotte and Milbrandt, 1998). Because Egr3 could have transient expression in DRG neurons during their development and potentially affect their ability to induce spindle morphogenesis, we examined newborn Egr3 ${ }^{+/ C r e} ; \mathrm{R}_{2} 6 \mathrm{R}^{+/ f l x}$ DRG using lacZ histochemistry. Although the majority of lacZ staining in DRG was present in intraganglionic nerve fibers (Fig. $2 A$, arrow), some DRG neurons expressed lacZ (Fig. $2 A$, left, arrowheads), but they never coexpressed the proprioceptive neuron marker Pv (Fig. 2A, right, arrowheads). Similar results were obtained using Ai14 Cre-recombinase reporter mice that express the tdTomato $(\mathrm{T})$ fluorophore regulated by a strong CAG promoter in Cre-recombinase-expressing cells (Madisen et al., 2010). Although there was strong $\mathrm{T}$ fluorescence in intraganglionic fibers in Egr3 ${ }^{+/ C r e}$; Ail ${ }^{+/ f l x}$ mice (Fig. $2 B$, left, arrow), there was never T fluorescence in $\mathrm{Pv}$-expressing proprioceptive neurons (Fig. $2 B$, middle, arrowheads and right, merge). Therefore, Egr3 is either never expressed in proprioceptive neurons or their precursors or expression is too low to express adequate levels of Cre-recombinase to activate the lacZ or T tracer alleles.

To determine whether low levels of Egr3 expression that may be undetectable using the genetic reporter mice could have a functional role in proprioceptive neurons and spindle morphogenesis, Egr3 conditional loss of function (Egr3-flx) mice were generated to ablate Egr3 expression in select cell lineages (Quach et al., 2013). Pv-Cre knock-in mice that efficiently recombine loxP sites in $\mathrm{Pv}$-expressing proprioceptive neurons (Hippenmeyer et al., 2005) were used to specifically disrupt the Egr3 locus within them. In $\mathrm{Pv}^{\mathrm{Cre} / \mathrm{Cre}}$; Egr $3^{\mathrm{fl} / \mathrm{fl} \mathrm{x}}$ (Prop-cKO) mice, $\mathrm{Pv}^{+} \mathrm{Ia}^{-}$ afferent axons (Fig. 2C, top, arrow) normally innervated Egr3expressing intrafusal muscle fibers (Fig. 2C, bottom, arrowhead) within structurally normal spindles. Although muscle spindle numbers were significantly decreased in mice lacking Egr3 in all tissues $\left(3^{-1-}\right)$, there were no structural abnormalities and no significant differences in the number of hindlimb spindles among wild-type $\left(3^{+/+}\right)$, Egr3-flx $\left(3^{\mathrm{fl} / \mathrm{fll} x}\right)$, or Prop-cKO adult gastrocnemius, plantaris, and soleus muscles (Fig. 2D). Moreover, whereas $3^{-1-}$ mice had significantly impaired performance on the rotarod, Prop-cKO mice showed no evidence of gait ataxia and performed no differently than $3^{+/+}$or $3^{\text {fle/flx }}$ mice (Fig. $2 E$ ). Therefore, Egr 3 does not have a functional role in propriocep- 
A

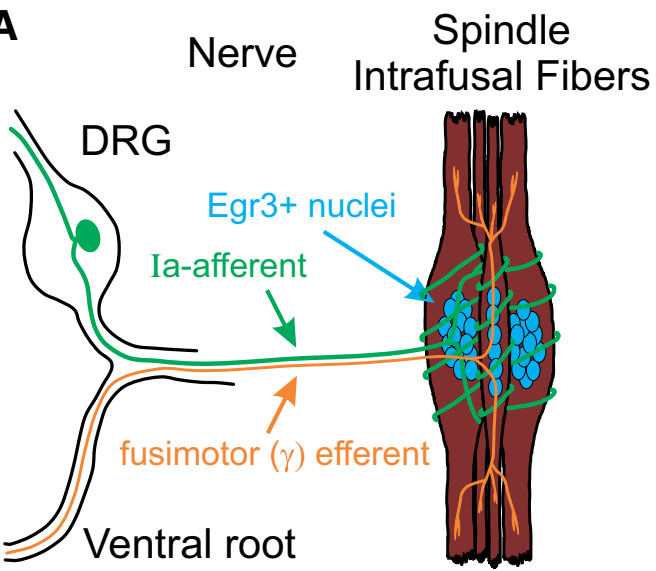

B

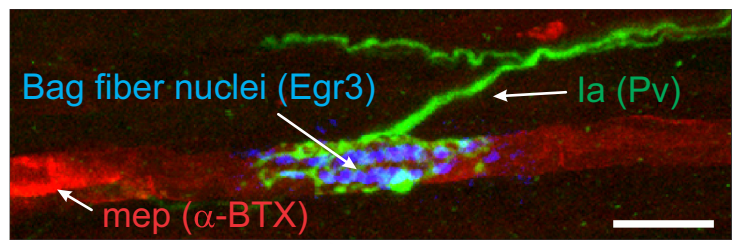

C Egr3-Cre allele

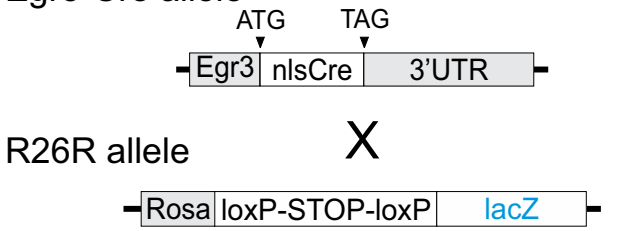

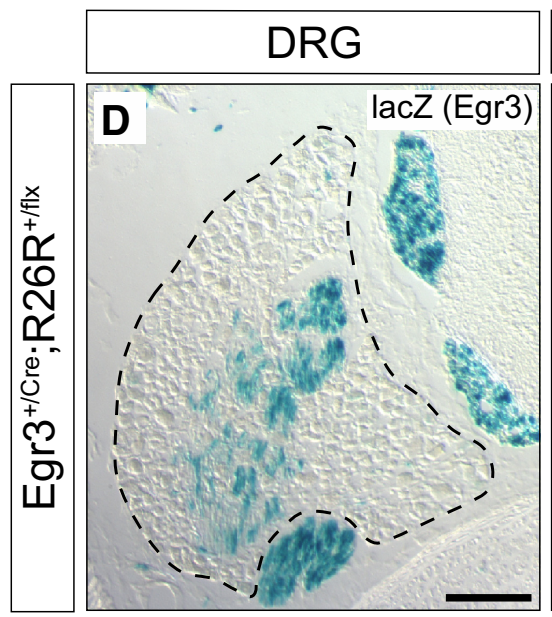
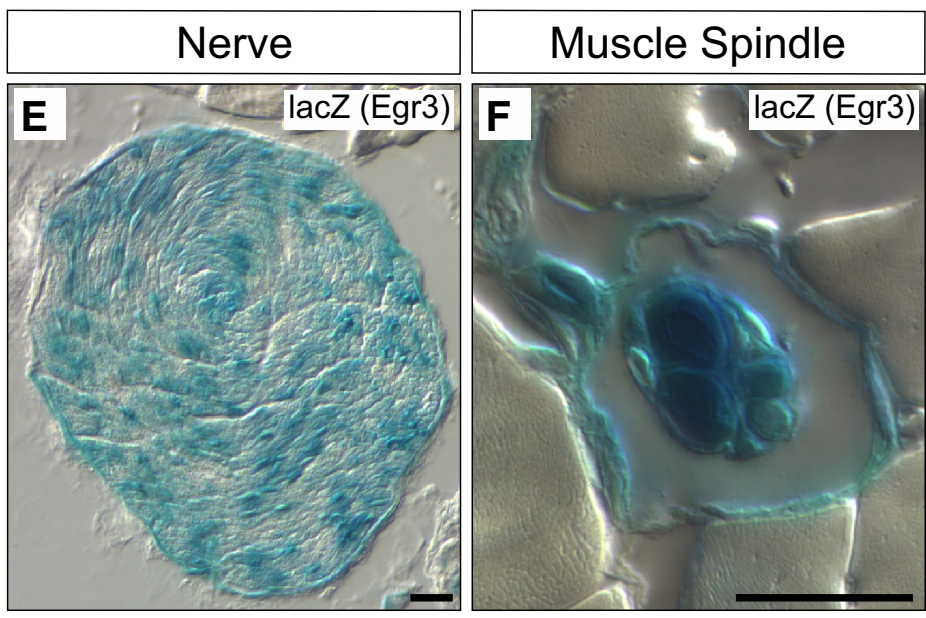

Figure 1. Egr3 expression in DRG, Schwann cells, and skeletal muscle. A, Muscle spindle intrafusal fibers receive group la (green) and group II (not shown) sensory innervation from DRG proprioceptive neurons that form anulospiral endings at the equatorial region of intrafusal muscle fibers. They are also innervated by fusimotor $(\gamma)$ axons from specialized spinal cord motor neurons that innervate near the polar ends of intrafusal muscle fibers (orange). $\boldsymbol{B}$, Whole-mount IHC from adult hindlimb soleus muscle spindle nuclear bag intrafusal muscle fiber innervated by a $\mathrm{Pv}^{+}{ }^{\mathrm{g}}$ roup la proprioceptive afferent axon that forms annulospiral contacts at the equatorial plane of the fiber (green). The transcription factor Egr3 is highly expressed in clustered intrafusal muscle fiber nuclei (blue) that lie subjacent to la-afferent axons (green). MEPs labeled by $\alpha$-BTX are detected at the polar ends of intrafusal fibers (red) where $(\gamma)$ fusimotor axons (not shown) form neuromuscular junctions. C, Egr3 ${ }^{+/ / \text {rre }}$ knock-in mice (Quach et al., 2013) were mated with R26R ${ }^{+/ f l x}$ reporter mice to trace historical Egr3 expression using $\beta$-gal histochemistry (lacZ) or immunofluorescence ( $\beta$-gal). The lacZ reaction product in Egr ${ }^{+/ / \mathrm{re}} ;$ R26R ${ }^{+/ f l x}$ mice is observed in DRG ( $\boldsymbol{D}$, dashed lines), Schwann cells in myelinated nerves $(\boldsymbol{E})$, and muscle spindles $(\boldsymbol{F})$, indicating historical expression of Egr3 in these tissues cellular precursors. Scale bars, $20 \mu \mathrm{m}$.

tive neurons to influence spindle morphogenesis or locomotor control.

\section{Egr3 expression in Schwann cells has no role in} spindle morphogenesis

Egr3 is expressed in Schwann cells, where it has a role in regulating the low-affinity nerve growth factor receptor (NGFR/p75) and myelin thickness in peripheral axons (Gao et al., 2007). Thickly myelinated group Ia-afferent axons induce spindle morphogenesis during development, raising the possibility that Egr3 could indirectly alter Ia-afferent function through a Schwanncell-dependent mechanism. For example, Egr2, a zinc-finger transcriptional regulator closely related to Egr3 (Christy and Nathans, 1989), is highly expressed in Schwann cells and has an essential role in peripheral axon myelination and function (Topilko et al., 1994; Warner et al., 1998; Bellone et al., 1999; Zorick et al., 1999; Le et al., 2005; Yun et al., 2010).

All Schwann cells labeled by the Schwann cell lineage marker $s 100 \beta$ were derived from an Egr3-expressing cell lineage because they all expressed the Egr3 lineage tracing marker (T) in Egr3 ${ }^{+/ C r e}$; Ail4 ${ }^{+/ f l x}$ myelinated nerves (Fig. $3 A$, arrow- head). In addition, many Schwann cells actively expressing Egr3 protein (Fig. $3 B$, arrowheads) were associated with $\mathrm{Pv}^{+}$ proprioceptive axons (Fig. $3 B$, arrows). To determine whether Egr3 function in Schwann cells can influence the function of Ia-afferents to induce spindle morphogenesis, Egr3 expression was selectively ablated in Schwann cells using myelin protein zero (P0)-Cre-recombinase transgenic mice (Feltri et al., 1999). Although Egr3 was ablated in $>90 \%$ of the P0 expressing Schwann cells in peripheral nerves in $\mathrm{P} 0-\mathrm{Cre}^{+} ; \mathrm{Egr} 3^{\text {flx/flx }}$ (SC-cKO) mutant mice (Fig. $3 C$ ), there were no significant differences in the number of spindles identified in the medial gastrocnemius, plantaris, or soleus muscles compared with $3^{+/+}$or $3^{\text {flx/flx }}$ mice (Fig. $3 D$ ). All of the muscle spindles had normal encapsulation, a characteristic subcapsular space of Sherrington at the equatorial plane and intrafusal muscle fiber nuclei that were normally centralized (data not shown). In addition, SC-cKO mice performed no differently than $3^{\text {flx/flx }}$ mice on the rotarod test (Fig. $3 E$ ). These results demonstrate that Egr3 expression in Schwann cells has no role in proprioceptive Ia-afferent-induced muscle spindle morphogenesis. 
Skeletal muscle specific ablation of Egr3 results in abnormal spindle

morphogenesis and abnormal proprioception

Egr3 is expressed in muscle spindle intrafusal fibers (Fig. $1 B, F$ ), but whether it has an intrafusal muscle fiber autonomous function in spindle development has not been demonstrated because previous studies were performed on mice lacking Egr3 in all tissues (Tourtellotte and Milbrandt, 1998; Tourtellotte et al., 2001). HSA-Cre transgenic mice were used to express Cre-recombinase regulated by the human skeletal actin (HSA) promoter in skeletal muscle (Miniou et al., 1999). Selective recombination of the Egr3-flx allele occurred in skeletal muscles (hindlimb and tongue shown) and to a lesser extent in cardiac muscle in $\mathrm{HSA}-\mathrm{Cre}^{+}$; Egr $3^{\mathrm{flx} / \mathrm{flx}}$ (SM-cKO) mice (Fig. 4A). Moreover, Egr3 expression was completely absent in newborn muscle spindles that were innervated by $\mathrm{Pv}^{+}$proprioceptive Ia-afferent axons (Fig. $4 B$, arrows) as previously reported for germline Egr3 knock-out $\left(3^{-1-}\right)$ mice lacking Egr3 in all tissues (Tourtellotte et al., 2001). Similar to $3^{-1-}$ mice and compared with wild-type $\left(3^{++}\right)$mice, identifiable muscle spindles were significantly reduced in medial gastrocnemius muscles to $6.1 \pm 0.3 \%(p<0.001)$, in plantaris muscles to $3.3 \pm 0.3 \%(p<0.001)$, and in soleus muscles to $15.2 \pm 0.3 \%(p<0.001)$ in adult SM-cKO mice (Fig. $4 C$ ). Moreover, SM-cKO mice had significantly impaired performance on rotarod (Fig. 4D) and treadmill (Fig. 4E) tests similar to $3^{-1-}$ mice compared with either $3^{+/+}$or $3^{\mathrm{flx} / \mathrm{flx}}$ mice. Therefore, Egr3 has an intrafusal muscle fiber autonomous role in spindle morphogenesis.

\section{Muscle spindle morphogenesis is blocked in Egr3-deficient mice}

In newborn germline $3^{-/-}$mice, previous studies showed that spindle morphogenesis was initiated and a normal number of morphologically abnormal spindle-like structures could be identified (Tourtellotte et al., 2001). Within a few days after birth, they were undetectable using standard histology, but whether they degenerated or fused with extrafusal muscle fibers was unknown because their fate beyond birth could not be traced using existing genetic and histological techniques.

Egr3 ${ }^{+/ C r e}$ knock-in mice are analogous to Egr3 heterozygote $\left(\right.$ Egr $\left.3^{+/-}\right)$mice and are phenotypically and behaviorally indistinguishable from wild-type mice (Quach et al., 2013). Using Egr3 ${ }^{+/ C r e}$ mice, it was possible to trace the fate of myotubes after the Egr3 promoter was activated within them by Ia-afferent contact during development, even if Egr3 expression was transient.
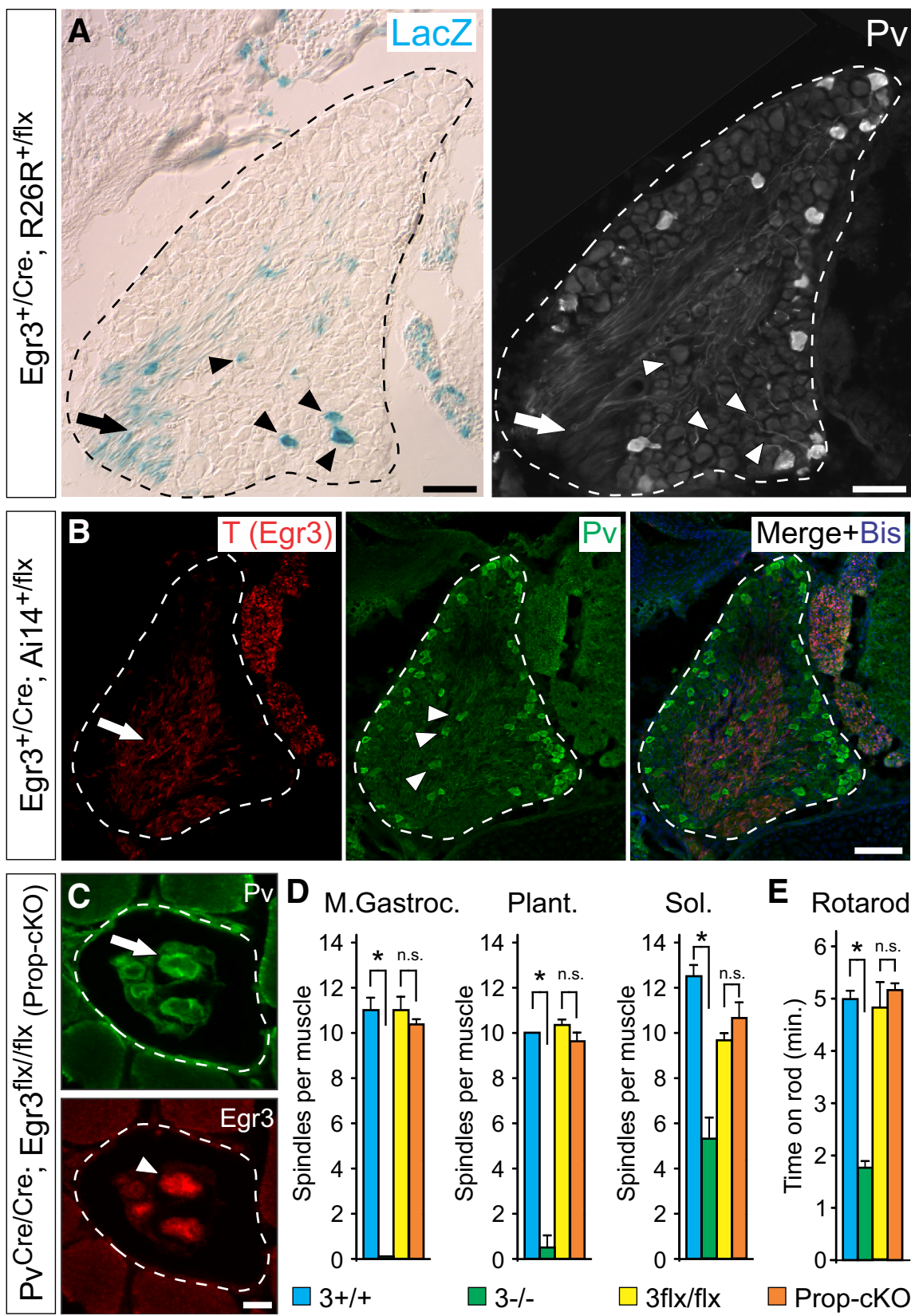

Sol.

E Rotarod
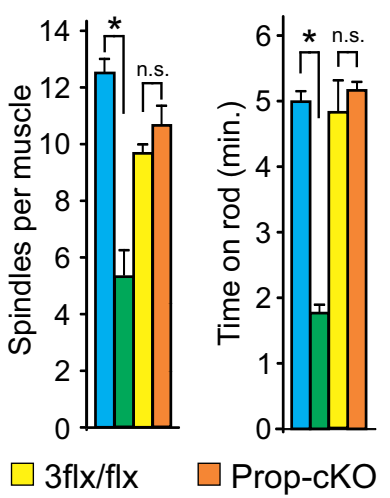

Figure 2. Egr3 has no role in proprioceptive neuron-dependent muscle spindle morphogenesis. $\boldsymbol{A}$, Left, Historical Egr3 expres-

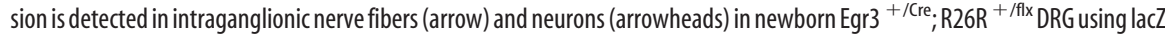
histochemistry. Right, However, no lac ${ }^{+}$proprioceptive neurons, labeled by Pv immunofluorescence, were identified. $\boldsymbol{B}$, Similarly, using Egr3 ${ }^{+/ C r e} ;$ Ai14 ${ }^{+/ f l x}$ mice, which express tandem dimer tomato (T; left, red) in Egr3-lineage-traced cells, no Pv ${ }^{+}$ neurons (middle, green) were found to coexpress T (historical Egr3 expression) ( $n=3$ mice, $>10$ DRG per mouse analyzed). $\boldsymbol{C}$, Adult skeletal muscle spindles from Pv ${ }^{\text {Cre/Cre; }}$ Egr3 ${ }^{\text {flx/flx }}$ (Prop-CKO) mice remain innervated by Pv ${ }^{+}$proprioceptive axons (top, green), which continue to express Egr3 (bottom, red) in intrafusal muscle fiber nuclei. D, Loss of Egr3 in proprioceptive neurons does not affect the number of muscle spindles in medial gastrocnemius, plantaris, or soleus hindlimb muscles of 8-week-old mice ( $n=3$ mice per muscle and genotype). $\boldsymbol{E}$, Prop-cK0 mice do not exhibit proprioceptive abnormalities as demonstrated by rotarod performance ( $n=8$ mice for each genotype) at 4 weeks of age. Scale bars: $\boldsymbol{A}, \boldsymbol{B}, 50 \mu \mathrm{m} ; \boldsymbol{C}, 10 \mu \mathrm{m} .{ }^{*} p<0.05$, Student's $t$ test.

Accordingly, lacZ histochemistry labeled muscle spindle capsules and all intrafusal muscle fibers in agreement with previously published Egr3 expression results (Tourtellotte and Milbrandt, 1998; Fig. $5 A$ ). In muscle, the lac $Z$ reaction product was confined to Schwann cells in myelinated axons, the muscle spindle capsule, and intrafusal muscle fibers, indicating that Egr3 is never expressed during development in lineage-specified extrafusal muscle fibers or their precursors. Because Ia-afferent axons contact 

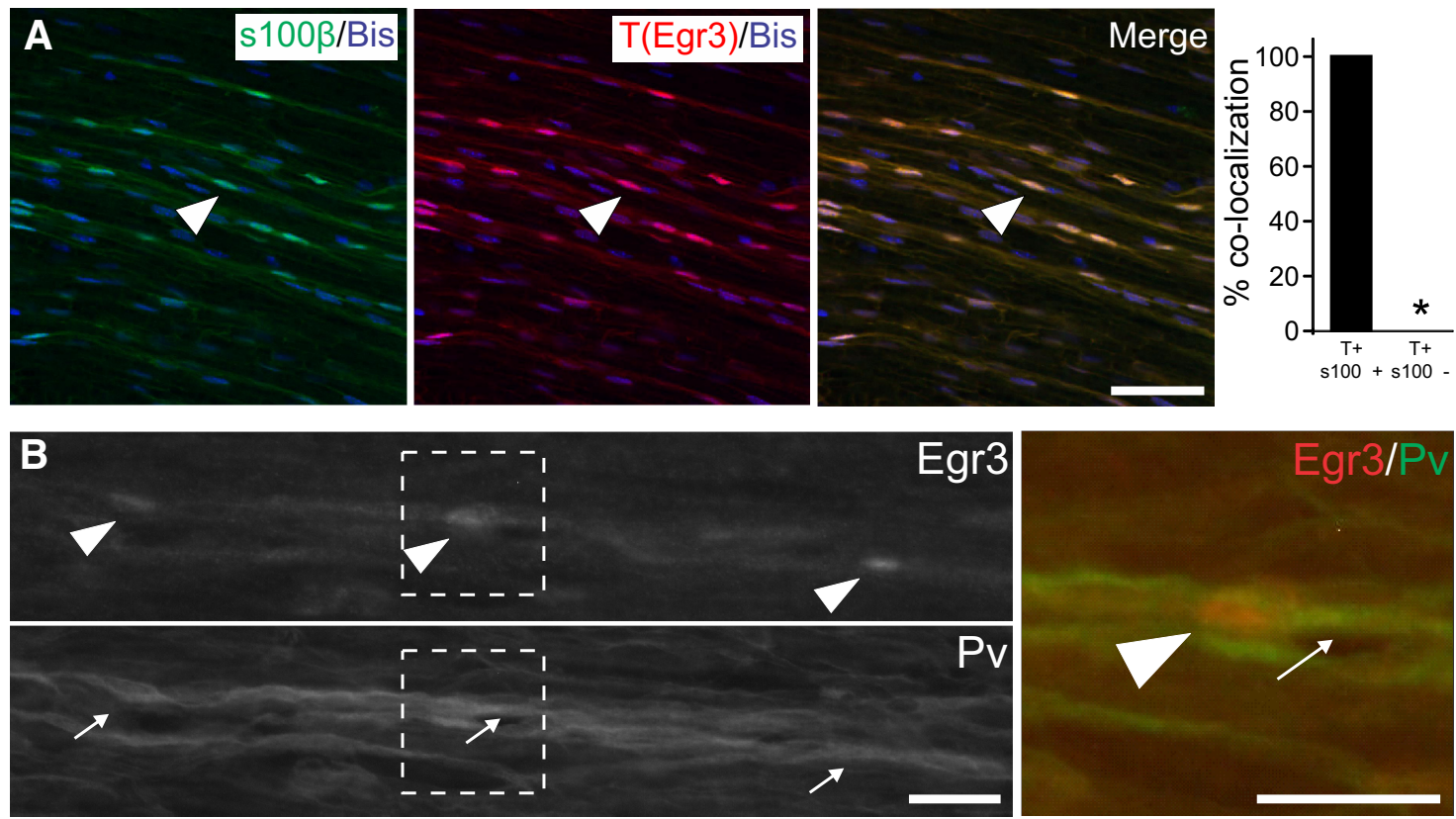

\section{C}

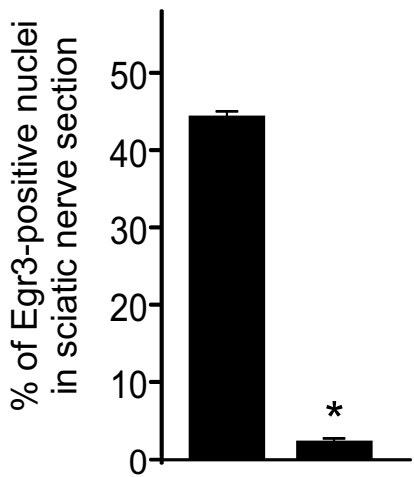

Ctl SC-cKO
D M.Gastroc.

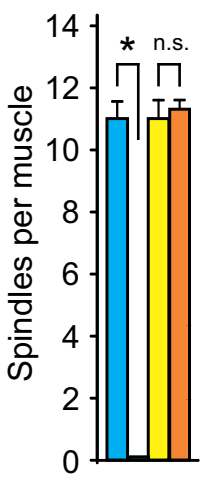

$3+/+$
Plant.

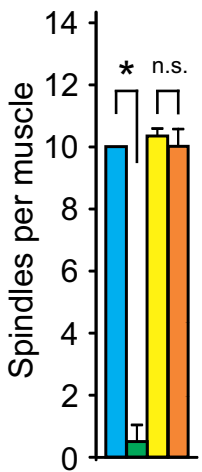

3-/-
Sol.

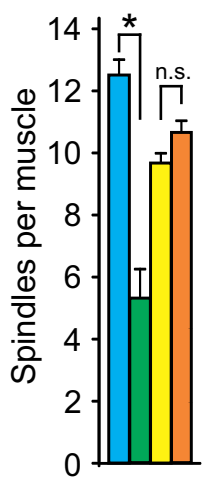

E Rotarod

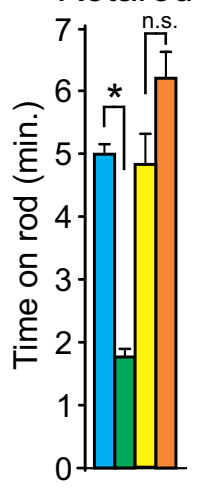

3flx/flx
SC-cKO

Figure 3. Egr3 expression in Schwann cells has no role in muscle spindle morphogenesis. $\boldsymbol{A}$, Egr3 lineage tracing in adult myelinated nerves (sciatic nerve shown) from Egr3 ${ }^{+/ / C r e} ;$ Ai14 ${ }^{+/ f l x}$ mice shows that all (100\%) of Schwann cells (identified using the Schwann cell marker s100 $\beta$, green) also expressed Egr3 (T, red) at some point during their development (Hoechst 33258/Bis nuclear counterstain, blue). $\boldsymbol{B}$, Egr3-expressing Schwann cells (red) are in direct contact with $\mathrm{Pv}^{+}$proprioceptive axons, raising the possibility that compromised Egr3 function in Schwann cells could affect proprioceptive axon function and induction of spindle morphogenesis. $\boldsymbol{C}$, In PO-Cre ${ }^{+}$; Egr $3^{\text {flx/flx }}$ (SC-cKO) mice, $>90 \%$ of Schwann cells lack Egr3 expression ( $n=3$ mice). $\boldsymbol{D}$, Egr3 ablation specifically in Schwann cells does not affect the number of muscle spindles in medial gastrocnemius, plantaris, or soleus hindlimb muscles in 8-week-0ld SC-cKO mice compared with P0-Cre ${ }^{-}$; Egr $3^{\text {flx } / f l x}(\mathrm{Ctl} ; n=3$ mice per muscle and per genotype). $\boldsymbol{E}$, Similarly, loss of Egr3 in Schwann cells does not lead to proprioceptive abnormalities as evaluated by the rotarod test ( $n=3$ mice for each genotype) at 4 weeks of age in SC-cKO mice, unlike Egr3-deficient $\left(3^{-1-}\right)$ mice, which showed a significant impairment in performance. Scale bars: $\boldsymbol{A}, 50 \mu \mathrm{m} ; \boldsymbol{B}, 20 \mu \mathrm{m}$. ${ }^{*} p<0.05$, Student's $t$ test.

myotubes during spindle morphogenesis, even in the absence of Egr3 (Tourtellotte et al., 2001), we reasoned that it would be possible to trace the fate of Egr3-deficient Ia-afferent contacted myotubes using Cre-recombinase-dependent reporter mice even when Egr3 was absent.

Egr $3^{\mathrm{Cre} / \mathrm{Cre}} ; \mathrm{R} 26 \mathrm{R}^{+/ f \mathrm{fl}}$ mice, which are equivalent to germline $3^{-1-}$ mice, were born at the expected Mendelian frequency and developed gait ataxia and proprioceptive abnormalities similar to germline $3^{-/-}$mice (data not shown). Using lacZ histochemistry, abnormal spindle-like structures, referred to as spindle remnants, were identified in Egr $3^{\mathrm{Cre} / \mathrm{Cre}} ; \mathrm{R}^{2} 6 \mathrm{R}^{+/ \mathrm{flx}}$ adult hindlimb muscles such as the gastrocnemius (Fig. $5 B$, center), plantaris (Fig. $5 C$, center), and soleus (Fig. 5D, center) muscles compared with normal muscle spindles that were identified in Egr3 ${ }^{+/ \mathrm{Cre}} ; \mathrm{R}_{2} 6 \mathrm{R}^{+/ \mathrm{flx}}$ mice (Fig. $5 B-D$, left). In all muscles examined from Egr $3^{\text {Cre/Cre }} ; \mathrm{R}_{26} \mathrm{R}^{+/}$ flx mice, clearly encapsulated lac $Z^{+}$muscle fibers were identified, confirming that the Egr3 promoter was activated in Ia-afferent- contacted myotubes and that spindle morphogenesis was initiated in the absence of Egr3 protein. Interestingly, there was a normal number of spindle remnants present in Egr $3^{\mathrm{Cre} / \mathrm{Cre}}$ muscles compared with the respective Egr $3^{+/ C r e}$ and wild-type $\left(3^{++}\right)$muscles (Fig. $5 B-D$, right). However, they contained only one to two encapsulated muscle fibers compared with the normal four to five intrafusal muscle fibers, they had no subcapsular space of Sherrington at their equatorial plane, the characteristic central nuclear clustering was absent, and their length was $<10 \%$ that of wild-type spindles. Moreover, LacZ expression was never identified in extrafusal muscle fibers, indicating that myotubes contacted by Ia-afferents did not fuse with extrafusal fibers in the absence of Egr3 protein. Therefore, spindle morphogenesis is initiated in a normal complement of Ia-afferent-contacted myotubes in the absence of Egr3, but the spindle remnants resemble immature muscle spindles that are blocked in their differentiation (Tourtellotte et al., 2001). 
A

B
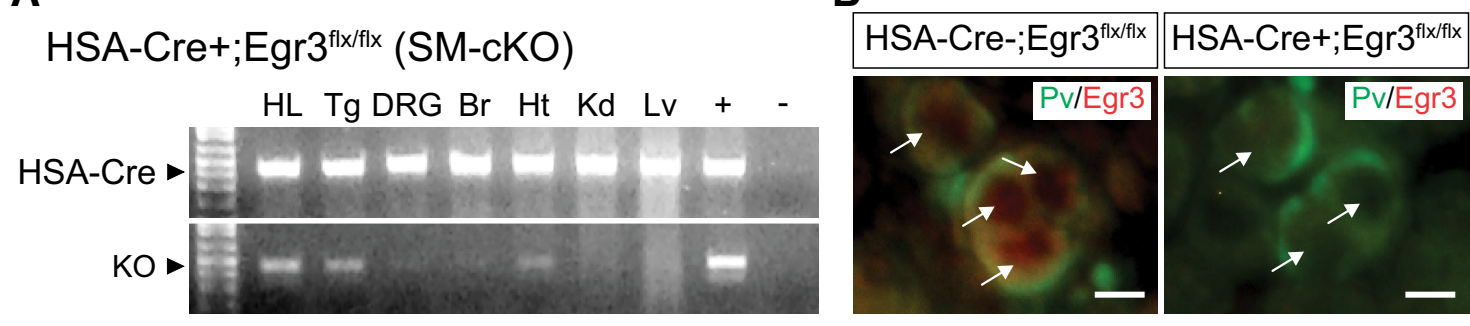

C
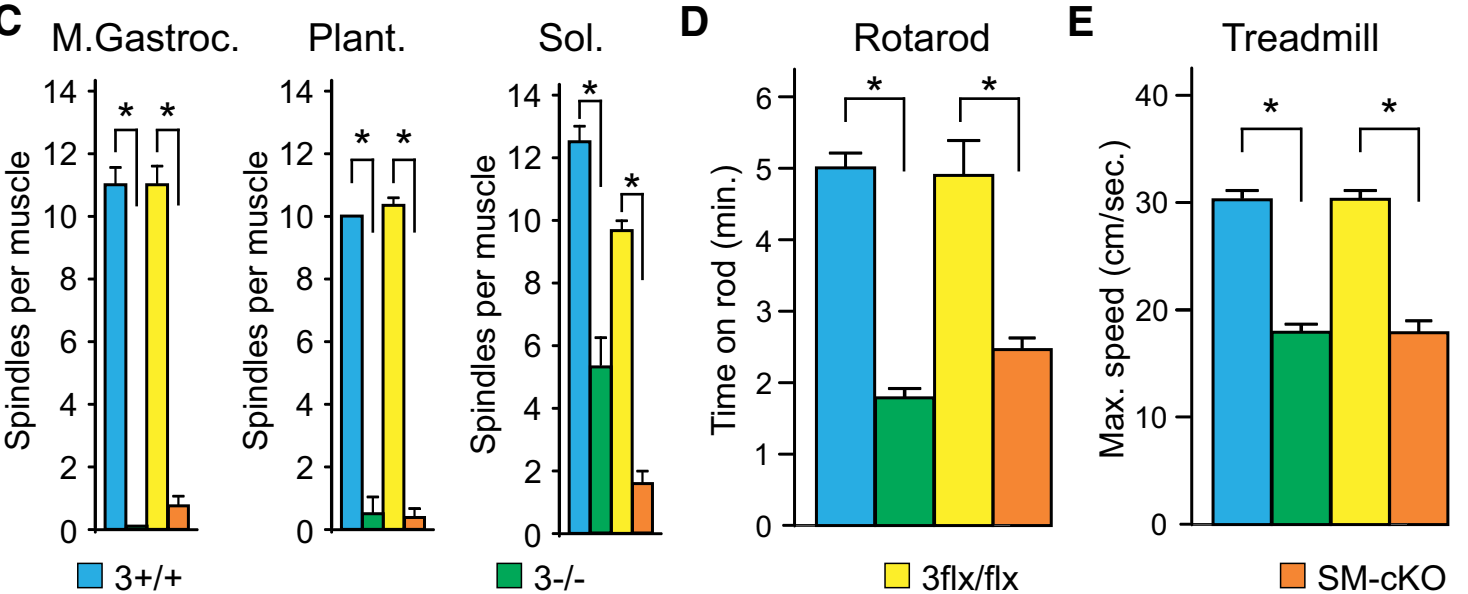

Figure 4. Loss of Egr3 specifically in skeletal muscle leads to abnormal spindle morphogenesis and proprioception. $A$, Genomic DNA PCR shows efficient skeletal muscle and some cardiac muscle recombination of the conditional Egr3 allele (KO) in HSA-Cre ${ }^{+}$; Egr3 ${ }^{\text {flx }}{ }^{f f x}$ mice. HL, Hindlimb; Tg, tongue; Br, brain; Ht, heart; Kd, kidney; Lv, liver. B, Proprioceptive axons labeled by Pv immunofluorescence (green)

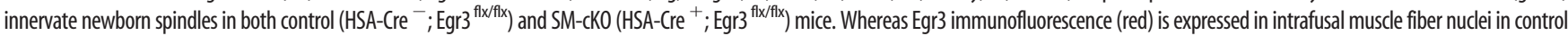
spindles, it is completely ablated in SM-cKO spindles. C, Using routine histology to identify spindles in tissue sections, muscle spindles are significantly decreased in number in 8-week-old SM-cKO medial gastrocnemius, plantaris, and soleusmuscles, similarto results obtained from germlineEgr3-deficient $\left(3^{-1-}\right)$ mice $(n=3$ micepermuscle). $\boldsymbol{D}, \boldsymbol{E}$, Rotarod $(\boldsymbol{D})$ and treadmill $(\boldsymbol{E})$ performanceby $S M-c K O$ miceat 4 weeks of age ( $n=4$ mice per genotype) is markedly abnormal compared with wild-type $\left(3^{+/+}\right)$and Egr3-ffx $\left(3^{\text {flx/flx }}\right)$ mice, but similar to germline Egr3-deficient $\left(3^{-/-}\right)$mice. Scale bar: $\boldsymbol{B}, 10 \mu$ m. ${ }^{*} p<0.001$, Student's $t$ test.

Previous studies indicated that Egr3 expression in developing intrafusal muscle fibers has an essential role in specifying their fate and differentiation (Albert et al., 2005). Therefore, we investigated whether intrafusal-like muscle fibers within spindle remnants expressed characteristic intrafusal lineage $\mathrm{MyHC}$ isoforms. The selective nuclear bag2 and chain intrafusal muscle fiber marker MF30 (neonatal and adult MyHC isoform) (Bader et al., 1982) was strongly expressed in muscle spindle intrafusal fibers from control Egr3 ${ }^{+/ C r e}$; R26R ${ }^{+/ f l x}$ mice (Fig. 6 A, top). However, spindle remnants that were traced by $\beta$-gal expression in 8 -weekold Egr3 ${ }^{\text {Cre/Cre }}$; R26R ${ }^{+/ f l x}$ littermate mice never expressed MF30 (Fig. 6A, bottom). MyHC isoforms BF-G6 (embryonic) (Schiaffino et al., 1986) and BA-F8 ( $\alpha$ and $\beta$ ) (Maier et al., 1988) were expressed in intrafusal muscle fibers of Egr3 ${ }^{+/ \mathrm{Cre}} ; \mathrm{R}_{2} 6 \mathrm{R}^{+/ \mathrm{flx}}$ spindles and were significantly decreased to $47 \pm 0.3 \%(p<$ $0.002)$ and $43 \pm 0.3 \%(p<0.002)$ of the $\beta$-gal ${ }^{+}$spindle remnants in Egr $3^{\text {Cre } / C r e} ; \mathrm{R}^{2} 6 \mathrm{R}^{+/ \text {flx }}$ mice, respectively (Fig. $6 \mathrm{~B}, \mathrm{C}$ ). In addition, $\beta$-gal ${ }^{+}$spindle remnants never expressed extrafusal muscle-fiber-specific MyHC isoforms such as 6H1 (fast, 2X) and 10F5 (fast, 2B), indicating that Egr3-deficient intrafusal-like muscle fibers do not acquire characteristic extrafusal muscle fiber $\mathrm{MyHC}$ expression (data not shown). These data indicate that, in the absence of Egr3, intrafusal muscle fiber morphogenesis is initiated, but differentiation is blocked at a point when they consist of only one or two fibers that do not acquire at least some characteristic intrafusally related $\mathrm{MyHC}$ expression. Although spindle remnants persist into adulthood, they have distinctly abnormal morphology and intrafusal muscle fiber biochemical ab- normalities that likely explain spindle function abnormalities in the absence of Egr3 (Chen et al., 2002; Akay et al., 2014).

Muscle spindle remnants lack fusimotor innervation and fail to express the fusimotor neuron survival factor GDNF

Muscle spindles are innervated by specialized motor (fusimotor) axons that regulate spindle sensitivity to stretch. Because $\beta$-gal ${ }^{+}$ spindle remnants in Egr $3^{\mathrm{Cre} / \mathrm{Cre}} ; \mathrm{R} 26 \mathrm{R}^{+/ \text {flx }}$ mice were found to be morphologically and biochemically abnormal, we investigated whether they were innervated by fusimotor axons. Serial sectioned hindlimb muscles from 8 -week-old mice were examined using immunofluorescence for ATP $1 \alpha 3$, a marker of fusimotor neurons and axons (Mata et al., 1991; Edwards et al., 2013), and $\alpha$-bungarotoxin ( $\alpha$-BTX) to label acetylcholine receptors at MEPs on intrafusal fibers. Interestingly, whereas $100 \%$ of the $\beta$-gal ${ }^{+}$spindles from Egr3 ${ }^{+/ \mathrm{Cre}} ; \mathrm{R} 26 \mathrm{R}^{+/ \mathrm{flx}}$ mice had evidence of ATP $1 \alpha 3^{+}$fusimotor innervation to $\alpha$-BTX ${ }^{+}$MEPs near their polar ends (Fig. $7 A$, top), none $(0 \%)$ of the $\beta$-gal ${ }^{+}$-traced spindle remnants from Egr $3^{\mathrm{Cre} / \mathrm{Cre}}$; R26R ${ }^{+/ \text {flx }}$ mice had evidence of fusimotor innervation or $\alpha$-BTX ${ }^{+}$MEP formation (Fig. 7A, bottom). Fusimotor axons were examined directly in lumbar (L4/ L5) ventral spinal roots from muscle-specific Egr3-deficient (SM-cKO) and littermate control mice. We found that $>80 \%$ of the small $(<3.5 \mu \mathrm{m})$ diameter axons, which represent fusimotor axons in the ventral nerve root (Tourtellotte and Milbrandt, 1998; Whitehead et al., 2005), were absent in SM-cKO relative to control mice (Fig. 7B). Therefore, intrafusal muscle fiber fusimotor innervation and MEP formation are Egr3 dependent. 


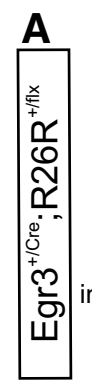

$\sim \mathrm{E} 15.5$

la-afferent

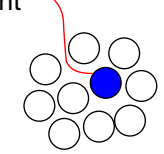

Egr3 promoter is activated in Ia-afferent contacted myotubes (lacZ is irreversibly expressed by Cre-recombinase)
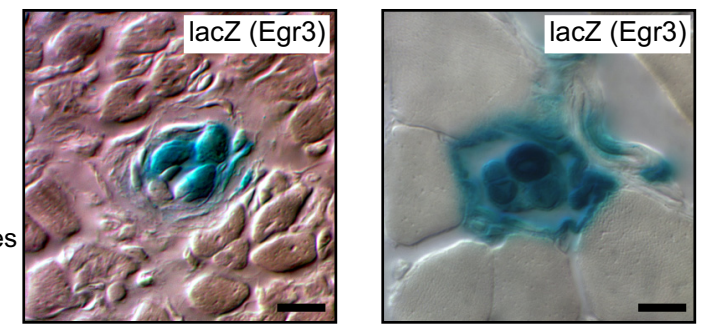

B
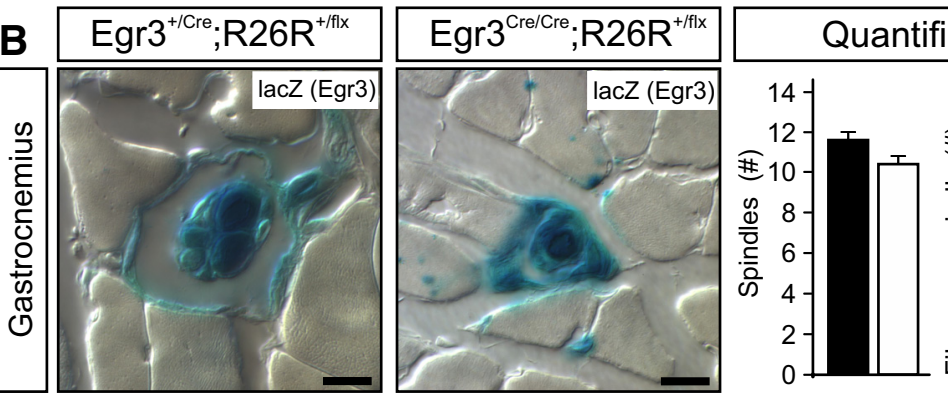

C
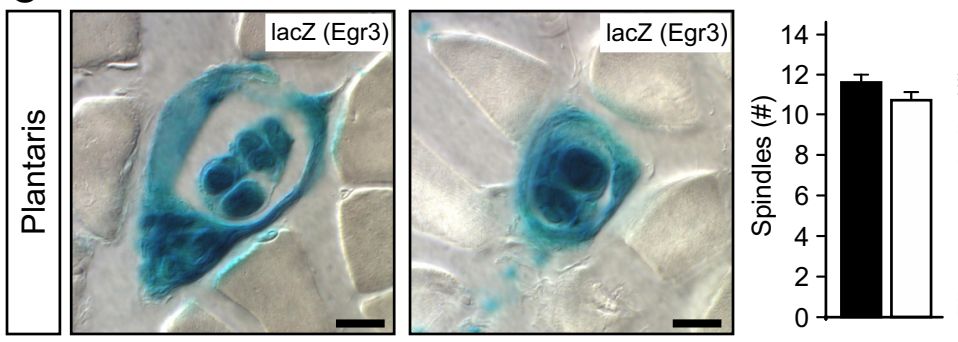

D
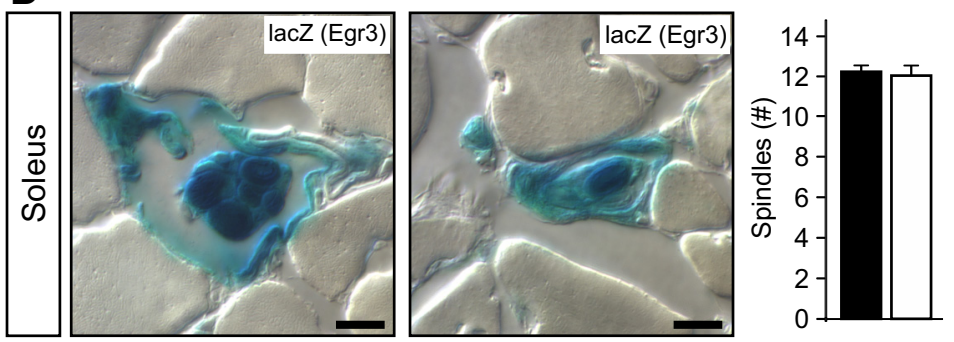

Figure 5. Egr3 lineage tracing identifies morphologically abnormal muscle spindle remnants that appear blocked in their differentiation. $\boldsymbol{A}$, la-afferent contacted myotubes induce Egr3 expression within them to irreversibly express $\beta$-gal (lac $Z$ ) in $\mathrm{Egr}^{+/ / \mathrm{Cre}} ; \mathrm{R} 26 \mathrm{R}^{+/ f \mathrm{fl}}$ mice. Egr3 lineage tracing in Egr3 ${ }^{+/ \mathrm{Cre}} ; \mathrm{R} 26 \mathrm{R}^{+/ \text {flx }}$ mice labels intrafusal muscle fibers and spindle capsules, similar to the normal pattern of Egr3 expression during spindle development (postnatal day 0 and 8-week-old spindles shown stained using lacZ histochemistry). $\boldsymbol{B}-\boldsymbol{D}$, Morphologically normal muscle spindles with a characteristic number per muscle and containing an average of four to five intrafusal muscle fibers are identified in three representative hindlimb muscles: $\boldsymbol{B}$ (left), medial gastrocnemius, $\boldsymbol{C}$ (left), plantaris, and $\boldsymbol{D}$ (left), soleus muscles in Egr3 ${ }^{+/ C r e} ;$ R26R ${ }^{+/ f l x}$ mice using lacZ histochemistry (blue). In Egr3-deficient muscles from Egr3 ${ }^{\text {Cre/Cre }} ; R_{2} 6 R^{+/ f f x}$ mice abnormal muscle spindle "remnants" (blue) are identified in $\boldsymbol{B}$ (center) medial gastrocnemius, $\boldsymbol{C}$ (center) plantaris, and $\boldsymbol{D}$ (center) soleus muscles by lineage tracing. There is no difference

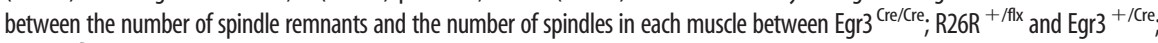
$\mathrm{R} 26 \mathrm{R}^{+/ f f x}$ mice, indicating that a full complement of spindles is induced and persists into adulthood in the absence of Egr3. However, spindle remnants in Egr3 ${ }^{\mathrm{Cre} / \mathrm{Cre}} ; \mathrm{R} 26 \mathrm{R}^{+/ / f x}$ mice have significantly reduced number of intrafusal fibers per spindle, indicating that the accumulation of intrafusal muscle fibers during normal spindle differentiation is blocked in the absence of Egr3. Muscle from 8-week-old animals is shown; $n=3$ mice for each muscle with $>30$ spindles or remnants examined. Scale bars, 20 $\mu \mathrm{m} .{ }^{*} p<0.05$, Student's $t$ test.

Muscle spindle expression of GDNF is essential for fusimotor neuron survival and intrafusal muscle fiber innervation (Whitehead et al., 2005; Gould et al., 2008; Shneider et al., 2009b). Whereas $100 \%$ of $\beta$-gal ${ }^{+}$spindles from Egr $3^{+/ \mathrm{Cre}} ; \mathrm{R}_{2} 6 \mathrm{R}^{+/ \mathrm{flx}}$ control mice expressed GDNF (Fig. $7 C$, top), $\beta$-gal ${ }^{+}$spindle remnants from Egr3 ${ }^{\mathrm{Cre} / \mathrm{Cre}}$; R26R ${ }^{+/ f \mathrm{~lx}}$ mice never $(0 \%)$ expressed
8 wks
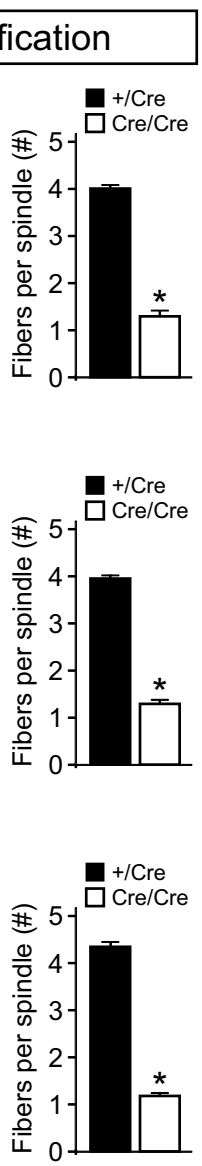

GDNF (Fig. 7C, bottom). Therefore, Egr3dependent GDNF expression in muscle spindle intrafusal muscle fibers correlates with, and may be responsible for, the loss of fusimotor innervation to spindle remnants in the absence of Egr3.

\section{Egr3-deficient muscle spindle remnants retain proprioceptive sensory innervation and express the} proprioceptive neuron survival factor NT3 Ia-afferent innervation to developing myotubes induces spindle morphogenesis (Zelená, 1957) and is required for normal structural development of spindle stretch receptors (Kucera and Walro, 1987). In $\mathrm{Egr}^{\mathrm{Cr} / \mathrm{Cre}}$; R26R ${ }^{+/ \mathrm{flx}}$ mice, spindle remnants are morphologically and biochemically abnormal, but they are present in normal numbers. These observations indicate that Ia-afferents innervate muscle and engage spindle induction in the absence of Egr3, but whether Ia-afferent innervation persists in Egr3-deficient remnants is not known. Similar to adult control Egr $3^{+/ C r e}$; $\mathrm{R}^{26 \mathrm{R}^{+/ f l x}}$ mice (Fig. $8 A$, top), in $\mathrm{Egr} 3^{\mathrm{Cre} / \mathrm{Cre}} ; \mathrm{R}^{26 \mathrm{R}^{+/ f l x}}$ mice, $100 \%$ of the $\beta-\mathrm{gal}^{+}$spindle remnants were innervated by $\mathrm{Pv}^{+}$Ia-afferents. The axons had a characteristic annulospiral configuration albeit with much less complexity and innervation of only one to two shortened fibers in the spindle remnants (Fig. 8A, bottom). Accordingly, the proprioceptive neuron survival factor NT3 (Ernfors et al., 1994; Kucera et al., 1995) was expressed in $100 \%$ of the $\beta$-gal ${ }^{+}$spindles in Egr3 ${ }^{+/ C r e} ; \mathrm{R}^{26 \mathrm{R}^{+f l x}}$ control spindles (Fig. $8 B$, top) and spindle remnants from Egr $3^{\text {Cre/Cre }} ; \mathrm{R} 26 \mathrm{R}^{+/ f l x}$ hindlimb muscles (Fig. $8 B$, bottom). These results indicate that, whereas Ia-afferent contact with intrafusal-like muscle fibers and the expression of its essential survival factor NT3 is maintained in adult spindle remnants, they are not sufficient to drive normal spindle development in the absence of Egr3.

\section{Discussion}

Proprioception abnormalities are present in many human neuropathies. Large-diameter myelinated sensory axons that mediate proprioception innervate muscle spindle mechanoreceptors (group Ia-afferents) and Golgi tendon organs (group Ib-afferents) and they can be selectively effected in acquired and congenital idiopathic neuropathies (Dalakas, 1986; Fukuda et al., 2000). Although dysfunctional proprioception can be caused by neuronal, axonal, or mechanoreceptor abnormalities, relatively little is known about how afferent innervation mediates mechanoreceptor development and innervation homeostasis. 

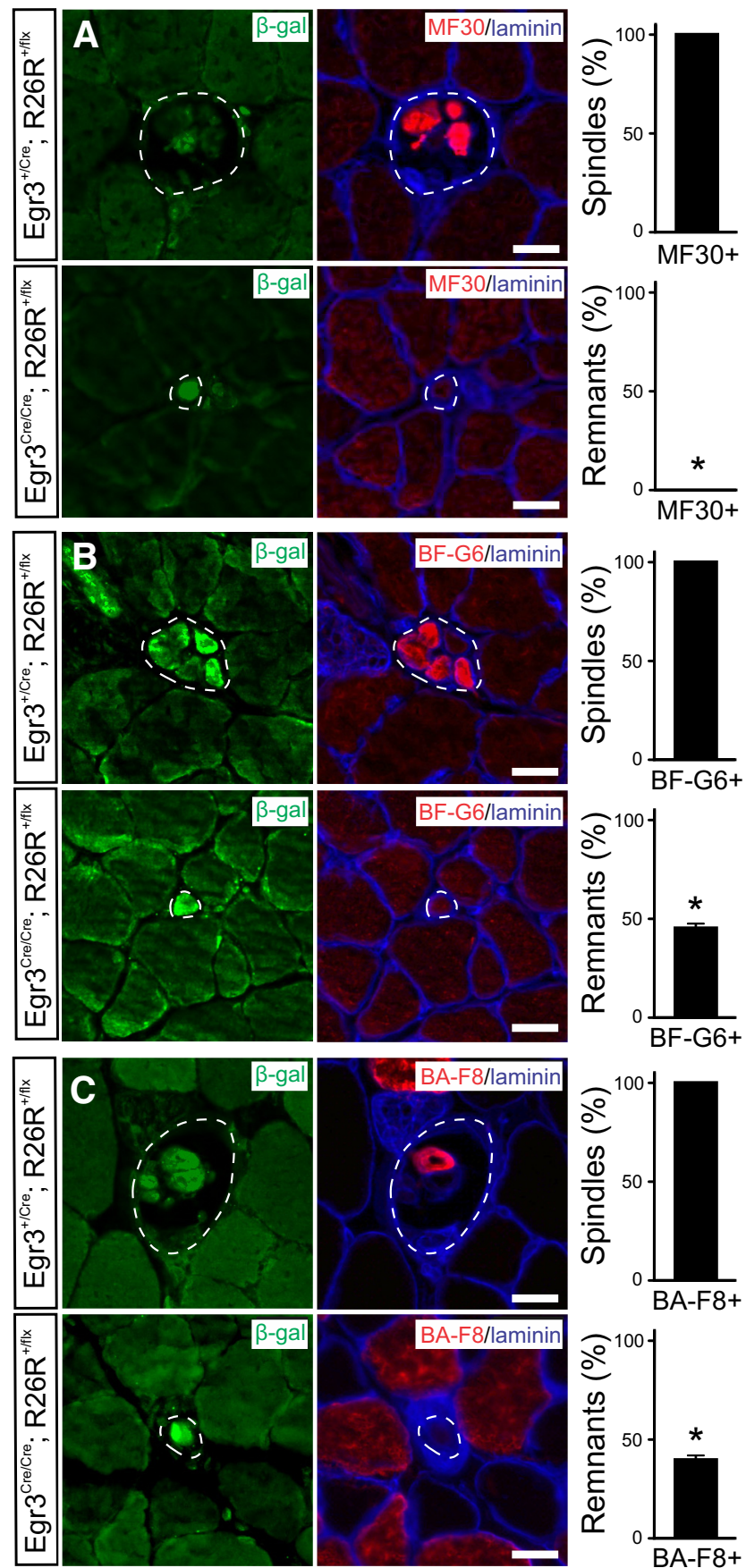

Figure 6. Egr3-deficient muscle spindle remnants have decreased expression of characteristic intrafusal muscle fiber proteins. $\boldsymbol{A}$, Top, All (100\%) of muscle spindles that express the Egr3 historical expression marker $\beta$-gal (green) have intrafusal muscle fibers expressing the neonatal and adult MyHC isoform (MF30, red) in control Egr3 ${ }^{+/ / \mathrm{Cre} ;}$ R26R $^{+/ f f x}$ mice. $A$, Bottom, However, $\beta$-gal ${ }^{+}$spindle remnants (green) from Egr3 ${ }^{\text {Cre/Cre }}$; R26R ${ }^{+/ f l x}$ mice never express MF30. B, Top, Embryonic MyHC (BF-G6, red) and C, Top, $\alpha$ and $\beta$ slow MyHC (BA-F8, red) isoforms are expressed in a characteristic pattern in all $(100 \%)$ of $\beta$-gal ${ }^{+}$control Egr3 ${ }^{+/ / \mathrm{ree}} ; \mathrm{R}^{2} 6 \mathrm{R}^{+/ \mathrm{flx}}$ muscle spindle intrafusal fibers (green). However, only $\boldsymbol{B}$ (bottom), $47 \pm 3 \% \beta$-gal ${ }^{+}$spindle remnants express $B \mathrm{~F}-\mathrm{G} 6$ and $\boldsymbol{C}$ (bottom), $43 \pm 3 \% \beta_{\text {-gal }}{ }^{+}$spindle remnants expressed BA-F8 in Egr3 ${ }^{\text {Cre/Cre, }}$ R26R ${ }^{+/ f x}$ mice. Soleus muscle from 8-week-old animals is shown; $n=30$ spindles or remnants analyzed per genotype; blue, laminin immunofluorescence. Scale bars, $20 \mu \mathrm{m} .{ }^{*} p<0.002$, Student's 5 test.

Ia-afferent, but not fusimotor efferent, innervation to skeletal muscle during development provides inductive signals in contacted myotubes that are essential for initiating spindle morphogenesis (Zelená, 1957; Zelená and Soukup, 1973; Kucera et al.,
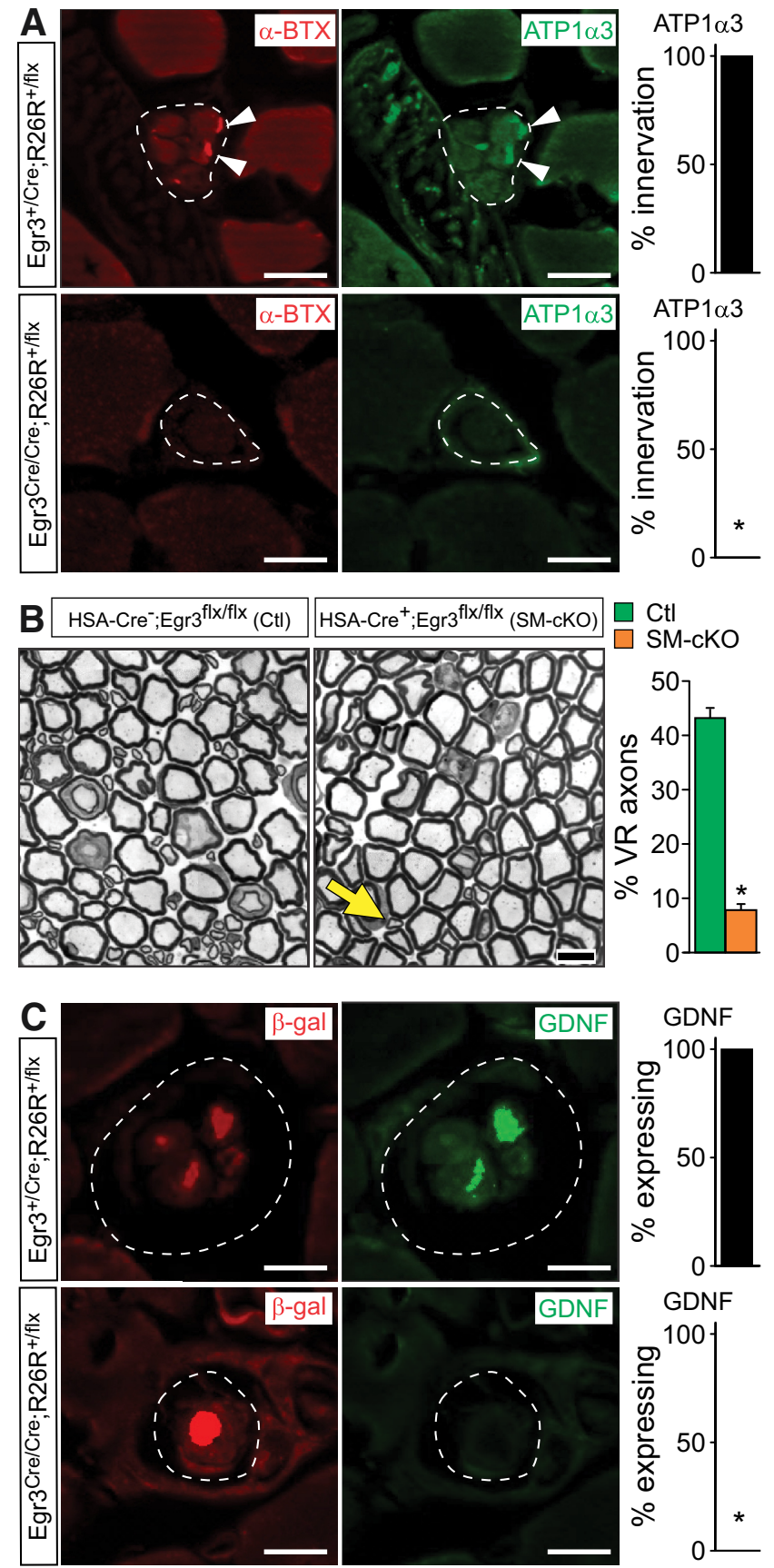

Figure 7. Egr3-deficient spindle remnants are not innervated by fusimotor axons and fail to express the fusimotor neuron survival factor GDNF. A, Top, All (100\%) of muscle spindles have MEPs near their polar ends that are visualized by $\alpha \mathrm{BTX}$ staining (red) and are innervated by fusimotor axons visualized by IHC for ATP $1 \alpha 3$ (green) in control Egr3 ${ }^{+/ / \mathrm{rre}} ; \mathrm{R}_{26 \mathrm{R}^{+/ f f x}}$ mice. $\boldsymbol{A}_{\text {, }}$ Bottom, However, neither MEPs nor ATP1 $\alpha 3^{+}$fusimotor axons are detected in $\beta$-gal ${ }^{+}$(data not shown) Egr3-deficient muscle spindle remnants from Egr3 ${ }^{\text {Cre/ } / \mathrm{ree}} ; \mathrm{R}^{26 \mathrm{R}^{+/ f f x}}$ mice (evaluated using serial section analysis). $\boldsymbol{B}$, Morphometric analysis using semithin sections of resin embedded adult ventral nerve roots from $\mathrm{HSA}_{-}-\mathrm{Cre}^{+}$; Egr3 ${ }^{\text {flx/flx }}$ (SM-cKO) mice showed a $>80 \%$ loss of small-diameter ( $<3.5 \mu \mathrm{m}$ axons, consistent with absent fusimotor axon innervation to spindle remnants in SM-CKO mice. C, Top, All (100\%) of $\beta$-gal ${ }^{+}$(red) spindles in

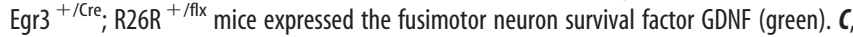
Bottom, However, none of the $\beta$-gal ${ }^{+}$(red) Egr3-deficient spindle remnants expressed GDNF (green) in Egr3 ${ }^{\text {Cre/(re; }}$, R26R ${ }^{+/ f l x}$ muscles using serial section analysis. Muscle from 8-week-old animals is shown; $n=30$ spindles or remnants analyzed per genotype in serial section. Scale bars, $10 \mu \mathrm{m}$. 

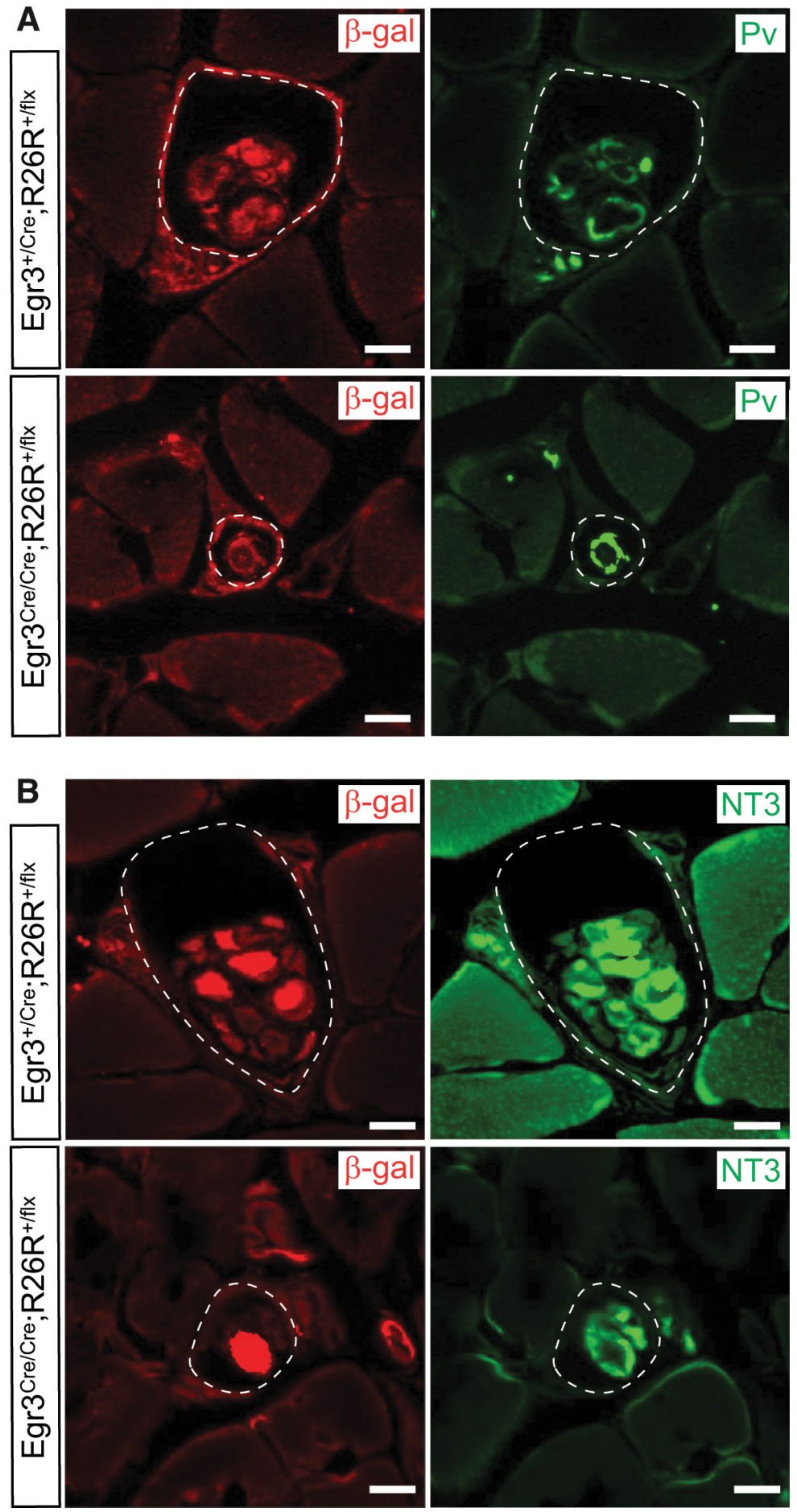

Figure 8. Egr3-deficient spindle remnants are innervated by proprioceptive la-afferent axons and express the proprioceptive neuron survival factor NT3. A, Top, All (100\%) of $\beta$-gal ${ }^{+}$(red) control muscle spindles in Egr3 ${ }^{+/ \mathrm{Cre}}$; $\mathrm{R}_{2} 6 \mathrm{R}^{+ \text {fflx }}$ mice are innervated by $\mathrm{Pv}^{+}$ la-afferent axons (green). $\boldsymbol{A}$, Bottom, Similarly, all (100\%) of $\beta$-gal ${ }^{+}$(red) Egr3-deficient spindle remnants in Egr3 ${ }^{\text {Cre/(rer } ; ~ R 26 R ~}{ }^{+/ f f x}$ mice are innervated by $\mathrm{Pv}^{+}$(green) Ia-afferent axons, although the remnants typically only contained one to two intrafusal fibers. $\boldsymbol{B}$, Top, All (100\%) of control $\beta$-gal ${ }^{+}$(red) spindles from Egr3 ${ }^{+/ / \text {re } ; ~}$ R26R ${ }^{+/ f f x}$ mice express the proprioceptiveneuron survival factor NT3 (green). $\boldsymbol{B}$, Bottom, Similarly, all (100\%) of $\beta$-gal ${ }^{+}$(red) spindle remnants from Egr3 ${ }^{\text {Cre/(ree; }}$ R26R ${ }^{+/ f l x}$ mice expressed NT3 (green). Muscle from 8-week-old animals is shown; $n=30$ spindles or remnants analyzed per genotype in serial section. Scale bars, $10 \mu \mathrm{m}$.

1995). Ia-afferent neurons require retrograde NT3 signaling from target muscles for survival and, accordingly, muscle spindles fail to form when NT3 or its cognate receptor TrkC (Ntrk3) are ablated in mice (Ernfors et al., 1994; Klein et al., 1994). Similarly, Ia-afferents liberate anterograde signaling molecules such
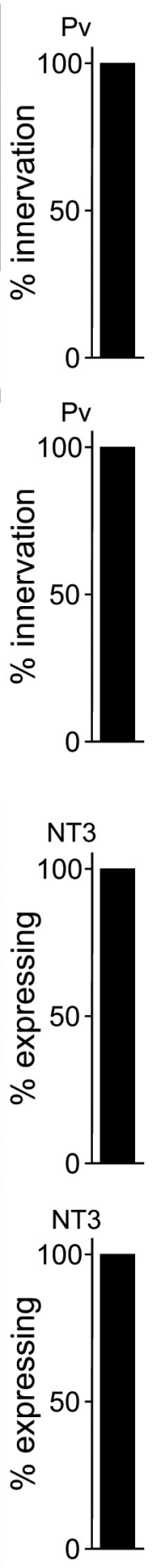

as Nrg1 that activates ErbB receptor signaling in contacted myotubes to induce spindle morphogenesis (Andrechek et al., 2002; Hippenmeyer et al., 2002; Leu et al., 2003). The transcriptional regulator Egr3 is induced by $\mathrm{Nrg} 1$ signaling in myotubes shortly after they are contacted by Iaafferents (Hippenmeyer et al., 2002; Jacobson et al., 2004; Herndon et al., 2014), but because Egr3 is expressed in many different cell types, its role in intrafusal muscle fiber development and innervation homeostasis within spindles has not been clearly defined. For example, Egr3 regulates dendrite morphology and terminal axon branching in sympathetic neurons and loss of Egr3 in sympathetic neurons leads to abnormal target tissue innervation and physiological dysautonomia (Eldredge et al., 2008; Li et al., 2011; Quach et al., 2013). Egr3 also has a role in Schwanncell-mediated axon myelination, at least in part by directly regulating the lowaffinity neurotrophin receptor p75 (Ngfr) (Gao et al., 2007). Therefore, Egr3 could have a role in proprioceptive neurons, their axon myelination, and/or intrafusal muscle fiber development that may be required for normal spindle morphogenesis.

Using conditional mutagenesis to ablate Egr3 selectively during early development in proprioceptive DRG neurons and Schwann cells, we found no abnormalities in muscle spindle morphogenesis or their function. However, when Egr3 was ablated in developing skeletal muscle, where it is expressed by intrafusal but not extrafusal skeletal muscle fibers, we found that Egr3 has an essential intrafusal muscle fiber autonomous role in their development. In previous studies using germline Egr3-deficient mice, it was not possible to trace the fate of Ia-afferent contacted myotubes because spindles could not be identified using routine histology in adult mice (Tourtellotte and Milbrandt, 1998; Tourtellotte et al., 2001). In the present study, using germline- and skeletalmuscle-specific Egr3-deficient mice, we were able to identify a small number of abnormal spindles in soleus muscle using routine histologic techniques. It may be that some spindle remnants were more easily identified in the soleus muscle because it consists of biochemically homogeneous slow-twitch fibers. Nevertheless, using fate mapping to trace Ia-afferentcontacted myotubes, we found that muscle spindle morphogenesis is engaged by Ia-afferent signaling at a normal frequency in all muscles, including the soleus muscle, in the absence of Egr3. However, the reporter-positive (genetically traced) spindles appeared as "spindle remnants" that contained only one to two encapsulated and shortened fibers in adult 
muscles. Muscle spindle remnants failed to develop into structurally normal or functional spindles, and their encapsulated muscle fibers lacked characteristic intrafusal muscle fiberrelated MyHC expression. Some MyHC proteins are differentially expressed in intrafusal muscle fibers (Kucera et al., 1992; Pedrosa-Domellöf et al., 1993; Pedrosa-Domellöf and Thornell, 1994; Kucera and Walro, 1995) and some depend on intact Iaafferent innervation (Kucera and Walro, 1988), but whether they are regulated by Egr3 in intrafusal muscle fibers is not known. We analyzed the expression of several MyHC proteins in skeletal muscle from 8 -week-old mice and found that genetically traced Egr3-deficient intrafusal muscle fibers do not normally express intrafusal muscle-fiber-associated MF30 (neonatal and adult), BF-G6 (neonatal), or BA-F8 (slow $\alpha / \beta)$ MyHC isoforms. Therefore, Egr3 appears to have a role in regulating gene expression related to intrafusal muscle fiber differentiation, consistent with previous studies suggesting that it has a role in Ia-afferentinduced myotube fate specification (Albert et al., 2005).

Although Egr3 does not have a role in proprioceptive neurons and Schwann cells during spindle morphogenesis, it may have an essential function in Ia-afferent-contacted myotubes that is required to establish or maintain their innervation. For example, spindle-derived signaling molecules regulate the strength of sensorimotor connections in the spinal cord, but not their formation or specificity (Shneider et al., 2009a). Given that sensorimotor synapses are poorly functional in Egr3-deficient mice, it is possible that Egr3 regulates retrograde signaling molecules (such as NT3) that strengthen sensorimotor connections or maintain peripheral Ia-afferent innervation with spindles (Chen et al., 2002). Indeed, previous studies suggested that spindle morphogenesis abnormalities in Egr3-deficient mice could be caused by nonpersistent Ia-afferent innervation due to loss of NT3 expression in Egr3-deficient intrafusal muscle fibers (Tourtellotte et al., 2001; Chen et al., 2002). However, in the present study, we systematically analyzed NT3 expression and Ia-afferent innervation using serial section analysis in genetically traced Egr3-deficient intrafusal muscle fibers from adult animals and found that all spindle remnants expressed NT3 and were innervated by Ia-afferents. Therefore, peripheral Ia-afferent innervation and spinal sensorimotor synaptic function in Egr3-deficient mice may be impaired because less muscle-derived NT3 is produced by a decreased number of poorly developed NT3-expressing intrafusal muscle fibers in spindle remnants compared with wild-type mice (Tourtellotte et al., 2001; Chen et al., 2002). Whether Egr3 regulates other retrograde signaling factors apart from NT3 that are involved in strengthening central sensorimotor synaptic function or promoting intrafusal muscle fiber differentiation remains to be determined. Nevertheless, the present results show conclusively that Egr3 has an intrafusal muscle fiber-autonomous role in their differentiation and development into a normal complement of intrafusal muscle fibers within an individual spindle. Egr3 does not appear to regulate initial Ia-afferent-myotube innervation, spindle morphogenesis induction, Ia-afferent innervation persistence, or NT3 expression in intrafusal muscle fibers.

Muscle spindles arise from single Ia-afferent contacted myotubes during embryogenesis, which undergo successive rounds of myotube fusion and splitting to generate multiple intrafusal muscle fibers within the encapsulated spindle core. At birth, when spindles are still developing, they receive innervation from fusimotor axons that are critical to maintaining intrafusal muscle fiber tone and stretch sensitivity, but have no signaling role in spindle morphogenesis (Zelená and Soukup, 1973; Kucera and Walro, 1992). Previous studies showed that fusimotor neurons and axons are absent in mice lacking Egr3, suggesting that spindles produce retrograde signaling that fusimotor neurons require for survival (Tourtellotte and Milbrandt, 1998; Enjin et al., 2012). GDNF may be one such factor because it is expressed by intrafusal muscle fibers (Whitehead et al., 2005) and previous studies suggest that it may have an important role in fusimotor neuron survival (Whitehead et al., 2005; Gould et al., 2008; Shneider et al., 2009b). In the present study, we found that genetically traced Egr3-deficient intrafusal muscle fibers in adult muscles fail to express GDNF and are not innervated by fusimotor axons, consistent with the hypothesis that GDNF is an essential spindlederived trophic factor required for fusimotor neuron survival. However, considering that Egr3-deficient intrafusal muscle fibers have biochemical abnormalities and structural shortening, it is also plausible that other processes such as abnormal axon target finding could contribute to abnormal target innervation and motor neuron survival. Whether Egr3 has a direct role in regulating GDNF expression in intrafusal muscle fibers or if Egr3-deficient intrafusal fibers lack GDNF expression because of an upstream block in their differentiation is not yet known.

In summary, the Ia-afferent axon-dependent Nrg1/ErbB signaling axis that regulates Egr3 expression has a profound, cellautonomous role in stretch receptor intrafusal muscle fiber differentiation. Failure of intrafusal muscle fibers to develop beyond one to two shortened fibers in the absence of Egr3, compared with four to five elongated fibers in wild-type spindles, leads to an overall decrease in the amount of NT3 available to innervating Ia-afferents during development. Relative depletion of spindle-derived NT3 is a likely explanation for the loss of most Ia-afferents and attenuated functional central sensorimotor synapses observed in Egr3-deficient mice (Tourtellotte and Milbrandt, 1998; Chen et al., 2002). This model is consistent with results showing that postnatal injection of NT3 into peripheral muscles can raise the level of NT3 available to existing Iaafferents at birth and rescue central sensorimotor synaptic function in the absence of Egr3 (Chen et al., 2002). Egr3 also appears to have a role in regulating GDNF expression in intrafusal muscle fibers, and thus their innervation by fusimotor axons, which explains the molecular basis for fusimotor neuropathy when spindles are abnormal, whether by loss of Egr3 or another mechanism. Improved understanding of the mechanisms involved in muscle stretch receptor innervation homeostasis and function will be essential for defining pathogenesis and formulating rational therapies for human sensory neuropathies with debilitating abnormalities in proprioception and locomotor control.

\section{References}

Akay T, Tourtellotte WG, Arber S, Jessell TM (2014) Degradation of mouse locomotor pattern in the absence of proprioceptive sensory feedback. Proc Natl Acad Sci U S A 111:16877-16882. CrossRef Medline

Albert Y, Whitehead J, Eldredge L, Carter J, Gao X, Tourtellotte WG (2005) Transcriptional regulation of myotube fate specification and intrafusal muscle fiber morphogenesis. J Cell Biol 169:257-268. CrossRef Medline

Andrechek ER, Hardy WR, Girgis-Gabardo AA, Perry RL, Butler R, Graham FL, Kahn RC, Rudnicki MA, Muller WJ (2002) ErbB2 is required for muscle spindle and myoblast cell survival. Mol Cell Biol 22:4714-4722. CrossRef Medline

Arber S, Ladle DR, Lin JH, Frank E, Jessell TM (2000) ETS gene Er81 controls the formation of functional connections between group Ia sensory afferents and motor neurons. Cell 101:485-498. CrossRef Medline

Bader D, Masaki T, Fischman DA (1982) Immunochemical analysis of myosin heavy chain during avian myogenesis in vivo and in vitro. J Cell Biol 95:763-770. CrossRef Medline

Bellone E, Di Maria E, Soriani S, Varese A, Doria LL, Ajmar F, Mandich P (1999) A novel mutation (D305V) in the early growth response 2 gene is 
associated with severe Charcot-Marie-Tooth type 1 disease. Hum Mutat 14:353-354. CrossRef Medline

Carter JH, Lefebvre JM, Wiest DL, Tourtellotte WG (2007) Redundant role for early growth response transcriptional regulators in thymocyte differentiation and survival. J Immunol 178:6796-6805. CrossRef Medline

Chen HH, Tourtellotte WG, Frank E (2002) Muscle spindle-derived neurotrophin 3 regulates synaptic connectivity between muscle sensory and motor neurons. J Neurosci 22:3512-3519. Medline

Christy B, Nathans D (1989) DNA binding site of the growth factorinducible protein Zif268. Proc Natl Acad Sci U S A 86:8737-8741. CrossRef Medline

Dalakas MC (1986) Chronic idiopathic ataxic neuropathy. Ann Neurol 19: 545-554. CrossRef Medline

Dunham NW, Miya TS (1957) A note on a simple apparatus for detecting neurological deficit in rats and mice. J Am Pharm Assoc Am Pharm Assoc (Baltim) 46:208-2090. Medline

Edwards IJ, Bruce G, Lawrenson C, Howe L, Clapcote SJ, Deuchars SA, Deuchars J (2013) $\mathrm{Na}+/ \mathrm{K}+$ ATPase alphal and alpha3 isoforms are differentially expressed in alpha- and gamma-motoneurons. J Neurosci 33: 9913-9919. CrossRef Medline

Eldredge LC, Gao XM, Quach DH, Li L, Han X, Lomasney J, Tourtellotte WG (2008) Abnormal sympathetic nervous system development and physiological dysautonomia in Egr3-deficient mice. Development 135:29492957. CrossRef Medline

Enjin A, Leão KE, Mikulovic S, Le Merre P, Tourtellotte WG, Kullander K (2012) Sensorimotor function is modulated by the serotonin receptor $1 \mathrm{~d}$, a novel marker for gamma motor neurons. Mol Cell Neurosci 49:322332. CrossRef Medline

Ernfors P, Lee KF, Kucera J, Jaenisch R (1994) Lack of neurotrophin-3 leads to deficiencies in the peripheral nervous system and loss of limb proprioceptive afferents. Cell 77:503-512. CrossRef Medline

Fariñas I, Jones KR, Backus C, Wang XY, Reichardt LF (1994) Severe sensory and sympathetic deficits in mice lacking neurotrophin-3. Nature 369:658-661. CrossRef Medline

Feltri ML, D'Antonio M, Previtali S, Fasolini M, Messing A, Wrabetz L (1999) P0-Cre transgenic mice for inactivation of adhesion molecules in Schwann cells. Ann N Y Acad Sci 883:116-123. CrossRef Medline

Fukuda M, Morimoto T, Suzuki Y, Kida K, Ohnishi A (2000) Congenital neuropathy with the absence of large myelinated fibers. Pediatr Neurol 23:349-351. CrossRef Medline

Gao X, Daugherty RL, Tourtellotte WG (2007) Regulation of low affinity neurotrophin receptor (p75(NTR)) by early growth response (Egr) transcriptional regulators. Mol Cell Neurosci 36:501-514. CrossRef Medline

Goodwin GM, McCloskey DI, Matthews PB (1972) The contribution of muscle afferents to kinaesthesia shown by vibration induced illusions of movement and by the effects of paralysing joint afferents. Brain 95:705748. CrossRef Medline

Gould TW, Yonemura S, Oppenheim RW, Ohmori S, Enomoto H (2008) The neurotrophic effects of glial cell line-derived neurotrophic factor on spinal motoneurons are restricted to fusimotor subtypes. J Neurosci 28: 2131-2146. CrossRef Medline

Herndon CA, Ankenbruck N, Fromm L (2014) The Erk MAP kinase pathway is activated at muscle spindles and is required for induction of the muscle spindle-specific gene Egr3 by neuregulin1. J Neurosci Res 92:174184. CrossRef Medline

Hippenmeyer S, Shneider NA, Birchmeier C, Burden SJ, Jessell TM, Arber S (2002) A role for neuregulin1 signaling in muscle spindle differentiation. Neuron 36:1035-1049. CrossRef Medline

Hippenmeyer S, Vrieseling E, Sigrist M, Portmann T, Laengle C, Ladle DR, Arber S (2005) A developmental switch in the response of DRG neurons to ETS transcription factor signaling. PLoS Biol 3:e159. CrossRef Medline

Jacobson C, Duggan D, Fischbach G (2004) Neuregulin induces the expression of transcription factors and myosin heavy chains typical of muscle spindles in cultured human muscle. Proc Natl Acad Sci U S A 101:1221812223. CrossRef Medline

Klein R, Silos-Santiago I, Smeyne RJ, Lira SA, Brambilla R, Bryant S, Zhang L, Snider WD, Barbacid M (1994) Disruption of the neurotrophin-3 receptor gene trkC eliminates la muscle afferents and results in abnormal movements. Nature 368:249-251. CrossRef Medline

Kucera J, Walro JM (1987) Postnatal maturation of spindles in deafferented rat soleus muscles. Anat Embryol 176:449-461. CrossRef Medline

Kucera J, Walro JM (1988) The effect of neonatal deafferentation or deffer- entation on myosin heavy chain expression in intrafusal muscle fibers of the rat. Histochemistry 90:151-160. CrossRef Medline

Kucera J, Walro JM (1992) Formation of muscle spindles in the absence of motor innervation. Neurosci Lett 145:47-50. CrossRef Medline

Kucera J, Walro JM (1995) Origin of intrafusal fibers from a subset of primary myotubes in the rat. Anat Embryol 192:149-158. Medline

Kucera J, Walro JM, Gorza L (1992) Expression of type-specific MHC isoforms in rat intrafusal muscle fibers. J Histochem Cytochem 40:293-307. CrossRef Medline

Kucera J, Fan G, Jaenisch R, Linnarsson S, Ernfors P (1995) Dependence of developing group Ia afferents on neurotrophin-3. J Comp Neurol 363: 307-320. CrossRef Medline

Le N, Nagarajan R, Wang JY, Araki T, Schmidt RE, Milbrandt J (2005) Analysis of congenital hypomyelinating Egr2Lo/Lo nerves identifies Sox 2 as an inhibitor of Schwann cell differentiation and myelination. Proc Natl Acad Sci U S A 102:2596-2601. CrossRef Medline

Leu M, Bellmunt E, Schwander M, Fariñas I, Brenner HR, Müller U (2003) Erbb2 regulates neuromuscular synapse formation and is essential for muscle spindle development. Development 130:2291-2301. CrossRef Medline

Lewandoski M, Meyers EN, Martin GR (1997) Analysis of Fgf8 gene function in vertebrate development. Cold Spring Harbor Symp Quant Biol 62:159-168. CrossRef Medline

Li L, Carter J, Gao X, Whitehead J, Tourtellotte WG (2005) The neuroplasticity-associated arc gene is a direct transcriptional target of early growth response (Egr) transcription factors. Mol Cell Biol 25: 10286-10300. CrossRef Medline

Li L, Eldredge LC, Quach DH, Honasoge A, Gruner K, Tourtellotte WG (2011) Egr3 dependent sympathetic target tissue innervation in the absence of neuron death. PLoS One 6:e25696. CrossRef Medline

Madisen L, Zwingman TA, Sunkin SM, Oh SW, Zariwala HA, Gu H, Ng LL, Palmiter RD, Hawrylycz MJ, Jones AR, Lein ES, Zeng H (2010) A robust and high-throughput Cre reporting and characterization system for the whole mouse brain. Nat Neurosci 13:133-140. CrossRef Medline

Maier A, Gorza L, Schiaffino S, Pette D (1988) A combined histochemical and immunohistochemical study on the dynamics of fast-to-slow fiber transformation in chronically stimulated rabbit muscle. Cell Tissue Res 254:59-68. Medline

Mata M, Siegel GJ, Hieber V, Beaty MW, Fink DJ (1991) Differential distribution of $(\mathrm{Na}, \mathrm{K})$-ATPase alpha isoform mRNAs in the peripheral nervous system. Brain Res 546:47-54. CrossRef Medline

Miniou P, Tiziano D, Frugier T, Roblot N, Le Meur M, Melki J (1999) Gene targeting restricted to mouse striated muscle lineage. Nucl Acids Res 27: e27. CrossRef Medline

Oakley RA, Garner AS, Large TH, Frank E (1995) Muscle sensory neurons require neurotrophin- 3 from peripheral tissues during the period of normal cell death. Development 121:1341-1350. Medline

Pedrosa-Domellöf F, Thornell LE (1994) Expression of myosin heavy chain isoforms in developing human muscle spindles. J Histochem Cytochem 42:77-88. CrossRef Medline

Pedrosa-Domellöf F, Gohlsch B, Thornell LE, Pette D (1993) Electrophoretically defined myosin heavy chain patterns of single human muscle spindles. FEBS Lett 335:239-242. CrossRef Medline

Poppele RE, Terzuolo CA (1968) Myotatic reflex: its input-output relation. Science 159:743-745. CrossRef Medline

Quach DH, Oliveira-Fernandes M, Gruner KA, Tourtellotte WG (2013) A sympathetic neuron autonomous role for Egr3-mediated gene regulation in dendrite morphogenesis and target tissue innervation. J Neurosci 33: 4570-4583. CrossRef Medline

Schiaffino S, Gorza L, Sartore S, Saggin L, Carli M (1986) Embryonic myosin heavy chain as a differentiation marker of developing human skeletal muscle and rhabdomyosarcoma: a monoclonal antibody study. Exp Cell Res 163:211-220. CrossRef Medline

Shneider NA, Mentis GZ, Schustak J, O’Donovan MJ (2009a) Functionally reduced sensorimotor connections form with normal specificity despite abnormal muscle spindle development: the role of spindle-derived neurotrophin 3. J Neurosci 29:4719-4735. CrossRef Medline

Shneider NA, Brown MN, Smith CA, Pickel J, Alvarez FJ (2009b) Gamma motor neurons express distinct genetic markers at birth and require muscle spindle-derived GDNF for postnatal survival. Neural Dev 4:42. CrossRef Medline 
Soriano P (1999) Generalized lacZ expression with the ROSA26 Cre reporter strain. Nat Genet 21:70-71. CrossRef Medline

Tessarollo L, Vogel KS, Palko ME, Reid SW, Parada LF (1994) Targeted mutation in the neurotrophin-3 gene results in loss of muscle sensory neurons. Proc Natl Acad Sci U S A 91:11844-11848. CrossRef Medline

Topilko P, Schneider-Maunoury S, Levi G, Baron-Van Evercooren A, Chennoufi AB, Seitanidou T, Babinet C, Charnay P (1994) Krox-20 controls myelination in the peripheral nervous system. Nature 371:796-799. CrossRef Medline

Tourtellotte WG, Milbrandt J (1998) Sensory ataxia and muscle spindle agenesis in mice lacking the transcription factor Egr3. Nat Genet 20:87-91. CrossRef Medline

Tourtellotte WG, Keller-Peck C, Milbrandt J, Kucera J (2001) The transcription factor Egr3 modulates sensory axon-myotube interactions during muscle spindle morphogenesis. Dev Biol 232:388-399. CrossRef Medline

Warner LE, Mancias P, Butler IJ, McDonald CM, Keppen L, Koob KG, Lupski JR (1998) Mutations in the early growth response 2 (EGR2) gene are associated with hereditary myelinopathies. Nat Genet 18:382-384. CrossRef Medline

Whitehead J, Keller-Peck C, Kucera J, Tourtellotte WG (2005) Glial cell-line derived neurotrophic factor-dependent fusimotor neuron survival during development. Mech Dev 122:27-41. CrossRef Medline

Yun B, Anderegg A, Menichella D, Wrabetz L, Feltri ML, Awatramani R (2010) MicroRNA-deficient Schwann cells display congenital hypomyelination. J Neurosci 30:7722-7728. CrossRef Medline

Zelená J (1957) The morphogenetic influence of innervation on the ontogenetic development of muscle spindles. Journal of Embryology and Experimental Morphology 5:283-292.

Zelená J, Soukup T (1973) Development of muscle spindles deprived of fusimotor innervation. Z Zellforsch Mikrosk Anat 144:435-452. CrossRef Medline

Zorick TS, Syroid DE, Brown A, Gridley T, Lemke G (1999) Krox-20 controls SCIP expression, cell cycle exit and susceptibility to apoptosis in developing myelinating Schwann cells. Development 126:1397-1406. Medline 